\title{
Clinical applications of schizophrenia genetics: genetic diagnosis, risk, and counseling in the molecular era
}

This article was published in the following Dove Press journal:

The Application of Clinical Genetics

20 February 2012

Number of times this article has been viewed

\author{
Gregory Costain 1,2 \\ Anne S Bassett ${ }^{1-4}$ \\ 'Clinical Genetics Research Program, \\ Centre for Addiction and Mental \\ Health, ${ }^{2}$ Institute of Medical Science, \\ University of Toronto, ${ }^{3}$ Division of \\ Cardiology, Department of Medicine \\ and Department of Psychiatry, \\ University Health Network, \\ ${ }^{4}$ Department of Psychiatry, University \\ of Toronto, Toronto, Ontario, Canada
}

Correspondence: Anne S Bassett Centre for Addiction and Mental Health, 33 Russell Street, Room I 100,Toronto, Ontario, Canada M5S 2SI

Tel +| $4|6535850|$ ext 273|

Fax + I 4165357199

Email anne.bassett@utoronto.ca

\begin{abstract}
Schizophrenia is a complex neuropsychiatric disease with documented clinical and genetic heterogeneity, and evidence for neurodevelopmental origins. Driven by new genetic technologies and advances in molecular medicine, there has recently been concrete progress in understanding some of the specific genetic causes of this serious psychiatric illness. In particular, several large rare structural variants have been convincingly associated with schizophrenia, in targeted studies over two decades with respect to $22 \mathrm{q} 11.2$ microdeletions, and more recently in large-scale, genome-wide case-control studies. These advances promise to help many families afflicted with this disease. In this review, we critically appraise recent developments in the field of schizophrenia genetics through the lens of immediate clinical applicability. Much work remains in translating the recent surge of genetic research discoveries into the clinic. The epidemiology and basic genetic parameters (such as penetrance and expression) of most genomic disorders associated with schizophrenia are not yet well characterized. To date, 22q11.2 deletion syndrome is the only established genetic subtype of schizophrenia of proven clinical relevance. We use this well-established association as a model to chart the pathway for translating emerging genetic discoveries into clinical practice. We also propose new directions for research involving general genetic risk prediction and counseling in schizophrenia.
\end{abstract}

Keywords: schizophrenia, genetics, 22q11 deletion syndrome, copy number variation, genetic counseling, genetic predisposition to disease

\section{Introduction}

Schizophrenia is arguably one of humankind's most severe diseases. ${ }^{1,2}$ Driven by new genetic technologies and advances in molecular medicine, recently there has been concrete progress in understanding some of the specific genetic origins of this complex psychiatric illness, summarized in several recent reviews. ${ }^{2-8}$ There has, however, been little focus on how we might practically apply the findings. ${ }^{9-11}$ In this review, we critically appraise recent developments in terms of immediate clinical utility. We use the well-established association of schizophrenia with microdeletion $22 \mathrm{q} 11.2$ as a model to chart the pathway for translating emerging genetic discoveries into clinical practice. We also propose new directions for research involving general genetic risk prediction and counseling in schizophrenia.

\section{Clinical features of schizophrenia ${ }^{9,12}$}

Schizophrenia is a common psychiatric illness that typically involves lifelong but treatable changes in thinking, behavior, and emotions. It has a lifetime morbid submit your manuscript | www.dovepress.com

Dovepress

http://dx.doi.org// 0.2147/TACG.S21953
The Application of Clinical Genetics 2012:5 I-18 which permits unrestricted noncommercial use, provided the original work is properly cited. 
risk of approximately $1 \%$. The principal symptoms are psychotic in nature: delusions (false beliefs), hallucinations (false perceptions), and thought disorder (disorganization of thought processes). In addition to these "positive" symptoms, there are also "negative" symptoms of blunted affect (reduced emotional expression), poverty of speech, anhedonia (reduced ability to feel pleasure), and amotivation, as well as disorganization of behavior and emotions. Depression, anxiety, irritability, agitation, sleep disturbance, and cognitive impairments, including changes in attention, memory, insight, and judgment, are also common. Onset of schizophrenia occurs most commonly in early adulthood from 17 to 30 years of age, but can arise in childhood (in $<1 \%$ of cases) through to the elderly age range. The diagnosis of schizophrenia is a clinical diagnosis, based on course of illness as well as cross-sectional symptoms. Diagnostic reliability is high when standard diagnostic criteria are combined with a direct examination and thorough history, including information from the patient, relatives, and others, to differentiate schizophrenia from other psychotic disorders. As with most neuropsychiatric disorders, there are no characteristic neuropathological findings (Table 1), which, coupled with the absence of any diagnostic tests and substantial clinical heterogeneity (variable signs and symptoms), emphasizes the importance of detailed expert phenotyping (cf "shallow phenotyping"). ${ }^{13}$

\section{Genetic epidemiology of schizophrenia}

Psychiatric genetics has historically focused in large part on the study of schizophrenia and its epidemiology. ${ }^{14}$ It is wellestablished that the heritability of schizophrenia is $>80 \%,{ }^{15-17}$ amongst the highest known for complex genetic disorders. ${ }^{18}$ Consistent evidence from family, twin, and adoption studies over the past century strongly indicates that predisposition is largely genetically determined (MIM \#181500). ${ }^{19-24}$ Nongenetic factors, for example, marijuana use and hypoxiamediated factors like birth complications or childhood head injury, increase risk for schizophrenia only modestly., ${ }^{9,25-32}$ Studies of schizophrenia in twins ${ }^{33,34}$ support reduced penetrance (genetic variants that do not express in every carrier as disease) and variable expression (variants that express as different diseases in different carriers), ${ }^{35,36}$ which is common to most human genetic diseases. As for most diseases, there is also substantial evidence for genetic heterogeneity and probably allelic heterogeneity. ${ }^{18,36}$ Gene-gene interaction (epistasis) is likely in schizophrenia ${ }^{37,38}$ and indeed is ubiquitous in nature. ${ }^{39}$ Molecular evidence for early predictions of spontaneous (de novo) mutations in schizophrenia, ${ }^{40,41}$

Table I Schizophrenia within the context of other common complex neuropsychiatric diseases (as of 20II)

\begin{tabular}{|c|c|c|c|c|c|}
\hline & Schizophrenia & ASD & Epilepsy & $\begin{array}{l}\text { Parkinson } \\
\text { disease }\end{array}$ & $\begin{array}{l}\text { Alzheimer } \\
\text { disease }\end{array}$ \\
\hline \multicolumn{6}{|l|}{ Clinical features } \\
\hline Approximate lifetime risk & $\sim 1 \%$ & $\sim 1 \%$ & $\sim 0.5 \%$ & $\sim 1.6 \%$ & $\sim 10 \%{ }^{\mathrm{a}}$ \\
\hline Typical onset & Young adulthood & Early childhood & Childhood & $\begin{array}{l}\text { Mid to late } \\
\text { adulthood }\end{array}$ & $\begin{array}{l}\text { Mid to late } \\
\text { adulthood }\end{array}$ \\
\hline Clinical heterogeneity & Yes & Yes & Yes & Yes & Yes \\
\hline Clinical diagnostic imaging/biomarker(s)/test(s) & No & No & Yes & No & No \\
\hline Definitive neuropathological diagnosis & No & No & No & Yes & Yes \\
\hline Primary mode of neuropathogenesis & Developmental & Developmental & Developmental & Degenerative & Degenerative \\
\hline \multicolumn{6}{|l|}{ Genetic features } \\
\hline Heritability & $>80 \%$ & $\sim 90 \%$ & $\sim 45 \%$ b & $\sim 30 \%$ & $\sim 70 \%$ \\
\hline Genetic heterogeneity & Yes & Yes & Yes & Yes & Yes \\
\hline Major common variant(s) & No & No & No & No & Yes \\
\hline Rare sequence mutation subtype(s) & No & Yes & Yes & Yes & Yes \\
\hline $\begin{array}{l}\text { Rare chromosomal anomaly/structural } \\
\text { mutation subtype(s) }\end{array}$ & Yes & Yes & Yes & No & Yes \\
\hline Genetic diagnosis changes medical management ${ }^{c}$ & Yes & No & Yes & No & No \\
\hline Pharmacogenetics as standard of care & No & No & No & No & No \\
\hline Routine use of genome-wide scans ${ }^{d}$ & No & Yes & No & No & No \\
\hline Family history as predominant recurrence risk factor & Yes & Yes & Yes & Yes & Yes \\
\hline Sources (reference numbers) & See text ${ }^{9}$ & $61,190,233,234$ & $235-239$ & $240-243$ & $244-247$ \\
\hline
\end{tabular}

Notes: ${ }^{a}$ Estimated based on risk after age 55-65 years, and therefore highly dependent on the mean life expectancy of the population; ${ }^{b}$ no consensus estimate, with a wide range of reports in the literature, ${ }^{235,239} \mathrm{c}$ management changed for the associated neuropsychiatric disease; this does not include more informed genetic counseling, the precipitation of other referrals or investigations, ${ }^{248}$ or the potential for earlier/more aggressive treatment as a result of early clinical diagnosis because of an increased index of suspicion; 'without accompanying developmental delay/mental retardation, ASD, or multiple congenital anomalies.

Abbreviation: ASD, autism spectrum disorder. 
recently reframed as the "common disease - rare alleles" model, ${ }^{42}$ adds to the complex genetic picture. Thus, it is not surprising, in hindsight, that classic Mendelian inheritance patterns are very rarely observed in schizophrenia, and that elucidation of causal genetic factors has been so challenging. Researchers have remained undeterred, because of the myriad possible benefits for patients, families, and clinicians that could result from an improved understanding of the genetic etiology of schizophrenia (Table 2).

\section{2 q I .2 deletion syndrome}

To date, $22 \mathrm{q} 11.2$ deletion syndrome (22q11.2DS; previously DiGeorge syndrome and velocardiofacial syndrome) is the only established genetic subtype of schizophrenia of proven clinical relevance. ${ }^{3,43}$ The association of $22 \mathrm{q} 11.2 \mathrm{DS}$ with schizophrenia followed soon after the discovery in the early 1990s that the 22q11.2 deletion was the underlying molecular anomaly unifying several, seemingly distinct, clinical syndromes first described in the 1960s and 1970s. ${ }^{44,45}$ Many of the features suggested above with respect to the genetic epidemiology of schizophrenia, including spontaneous mutations, reduced penetrance, and variable expressivity, are found in 22q11.2DS.

\section{Molecular origins and epidemiology}

$22 \mathrm{q} 11.2 \mathrm{DS}$ is associated with a hemizygous microdeletion on chromosome 22q11.2 of variable length (typically $3 \mathrm{Mb}$ ) and, in some cases, variable position within this region., ${ }^{9,46}$ There is no apparent critical region at this locus for any major phenotype, including schizophrenia. ${ }^{47-50}$ Most deletions are flanked by segmental duplications ${ }^{51}$ and occur as de novo mutations mediated by nonallelic homologous recombination. ${ }^{46,52}$ Only $5 \%-10 \%$ of cases have been found to be inherited from transmitting parents, ${ }^{53-56}$ most frequently mothers with mild neuropsychiatric phenotypes. ${ }^{57}$ Nevertheless, 22q11.2DS is the most common genomic disorder ${ }^{58}$ in humans, with an oft-cited estimated prevalence in the general population of 1 in 3000-4000 live births that is likely to be an underestimate. ${ }^{59,60}$ Fluorescence in situ hybridization using a standard 22q11.2 probe (D22S75 or

Table 2 Potential future roles for molecular genetics in the clinical management of schizophrenia

\begin{tabular}{|c|c|}
\hline Area of benefit & Details and examples \\
\hline \multicolumn{2}{|c|}{ Medical (of primary benefit to the clinician and patient) } \\
\hline \multirow[t]{6}{*}{ Prediction and prevention } & - Personalized genetic (ie, inborn) lifetime risk for psychosis* \\
\hline & - Narrowing of window for age at onset in high risk cases \\
\hline & - Personalized neurocognitive and/or neuroimaging precursors of psychosis \\
\hline & - Opportunity to limit important deleterious gene by environment interactions \\
\hline & - Anticipation of potential extra-psychiatric features* \\
\hline & - Tailored early interventions to delay or prevent onset, or attenuate course \\
\hline Diagnosis & $\begin{array}{l}\text { - At first onset of psychosis, higher index of suspicion for schizophrenia (as a result of improvements } \\
\text { in prediction)* }\end{array}$ \\
\hline Management & $\begin{array}{l}\text { - Coordinated multisystem management and anticipatory care for possible extra-psychiatric manifestations } \\
\text { of causal genetic variant(s)* }\end{array}$ \\
\hline \multirow[t]{6}{*}{ Treatment } & - Earlier/more aggressive treatment (as a result of improvements in prediction and diagnosis)* \\
\hline & - Preference for or avoidance of particular antipsychotic medications \\
\hline & - Tailored dosing (eg, via knowledge of fast and slow metabolizers; pharmacogenomics) \\
\hline & - Less potential confusion of medication side effects with extra-psychiatric manifestations \\
\hline & of causal genetic variant(s) (eg, metabolic syndrome, parkinsonism, seizures)* \\
\hline & - Novel personalized therapeutic targets \\
\hline \multirow[t]{2}{*}{ Prognosis } & $\begin{array}{l}\text { - Improved course (as a result of improvements in prediction/prevention, diagnosis, } \\
\text { treatment, and management)* }\end{array}$ \\
\hline & - Personalized data on natural history and longevity* \\
\hline \multicolumn{2}{|c|}{ Psychosocial (of primary benefit to the patient and family) } \\
\hline \multirow[t]{3}{*}{ Understanding } & - Partial answer to the question, "Why me?"* \\
\hline & - Explanation for potential premorbid developmental signs and symptoms (eg, learning difficulties)* \\
\hline & $\begin{array}{l}\text { - Extra reassurance that parenting or personal life choices did not play a major role in causing } \\
\text { the illness* }\end{array}$ \\
\hline \multirow[t]{2}{*}{ Counseling } & - Personalized recurrence risks for family members* \\
\hline & - Better informed reproductive decision making and possibility for prenatal detection* \\
\hline \multirow[t]{2}{*}{ Hope } & - Proof of progress in understanding the illness* \\
\hline & - Prospect of continued improvements in treatment and management, as above* \\
\hline
\end{tabular}

Note: *Already possible for 22q II.2 deletion syndrome (22q I I.2DS) subtype of schizophrenia (see text for details). 
TUPLE1) has been used since 1992 to detect most deletions in this region, ${ }^{9}$ but is now being superseded by clinical microarrays that should increase diagnostic yield. ${ }^{46,61,62}$ Several lines of evidence support the generally pathogenic nature of $22 \mathrm{q} 11.2$ deletions and the high penetrance of observable phenotypes, ${ }^{3,63,64}$ so that no distinction is typically made between individuals with 22q11.2 deletions and individuals with $22 \mathrm{q} 11.2 \mathrm{DS}$.

\section{Association with schizophrenia}

Several studies have confirmed that 22q11.2DS accounts for approximately $1 \%$ of all cases of schizophrenia (see Bassett et $\mathrm{al}^{65}$ and references therein). Conversely, an estimated $22.5 \%$ of adults with 22 q11.2DS develop schizophrenia ${ }^{66}$ or a related psychotic disorder. ${ }^{67}$ In other words, a $22 \mathrm{q} 11.2$ deletion is a variant of large effect, associated with a greater than 20 -fold increase in risk for schizophrenia. ${ }^{9}$ The clinical expression of the schizophrenic illness is essentially indistinguishable from that found in the general population with respect to prodrome, age at onset, presentation, cognitive profile (except for lower mean IQ), and, according to limited data available, response to treatment. ${ }^{43,66-71}$ Thus $22 \mathrm{q} 11.2 \mathrm{DS}$ represents the best available specific genetic model of schizophrenia, with minimized genetic heterogeneity and substantial evidence this is a representative form of this illness. ${ }^{2}$ Empirical evidence for a strong negative selective pressure ${ }^{57}$ and high rate of recombination at the $22 \mathrm{q} 11.2$ locus $^{72}$ is consistent with the common disease - rare variant model for schizophrenia. ${ }^{42}$

\section{Clinical relevance}

For patients with schizophrenia, a clinician today should be armed with a high index of suspicion for 22q11.2DS and/ or consistently use established clinical screening criteria to detect features suggesting this genetic diagnosis, such as dysmorphic facies, a nasal voice, congenital anomalies, and/or learning difficulties. ${ }^{65,73}$ This would prompt a comprehensive diagnostic assessment, including developmental, medical, and family history, and a physical examination by a clinician experienced in genetic syndromes and dysmorphology. ${ }^{9}$ Genetic testing would follow if sufficient features were present to support a clinical diagnosis of $22 \mathrm{q} 11.2 \mathrm{DS}^{73}$ and should proceed in all patients with comorbid mental retardation and/or multiple congenital anomalies. ${ }^{3,61}$

In a patient with schizophrenia, detection of a $22 \mathrm{q} 11.2$ deletion is clinically relevant. ${ }^{9}$ Consensus clinical practice guidelines ${ }^{46}$ now exist that detail opportunities for anticipatory care and optimizing medical management of associated features, and for genetic counseling that can be informed by extensive (and rapidly expanding) knowledge of pathogenesis, recurrence risk, and lifelong expression, natural history, and clinical outcomes. ${ }^{54,56,57,63,66,67,70,74-88}$ Careful attention to the commonly accompanying endocrine and neurological features in particular may be helpful in the psychiatric management of patients with $22 \mathrm{q} 11.2 \mathrm{DS}$. ${ }^{9,63}$ As is common in patients with schizophrenia, the psychiatrist may be the only physician the patient sees regularly and may therefore be expected to provide primary care for accompanying medical conditions, and/or have the responsibility for arranging appropriate investigations and follow-up.

For patients already diagnosed with 22q11.2DS, what are the potential implications of knowing about the risk for schizophrenia prior to first onset of psychosis? As for schizophrenia in the general population, ${ }^{29}$ there is little evidence for any additional environmental factor(s) affecting risk of psychosis in 22q11.2DS. ${ }^{9,89}$ Avoiding substance use, particularly early marijuana use, and lifelong general health measures such as good nutrition, and physical and mental exercise, may decrease risk to some extent. ${ }^{9}$ Common genetic modifiers of some effect may exist, ${ }^{90,91}$ as for the congenital cardiac phenotype, ${ }^{92,93}$ but have not been convincingly demonstrated ${ }^{67,94-96}$ (see Philip and Bassett ${ }^{48}$ for more details), and additional copy number variation/variants (CNV) do not seem to play a major role in expression of schizophrenia. ${ }^{53}$ Prospective ${ }^{97-99}$ and retrospective ${ }^{68,70,100}$ research is ongoing to identify specific neurocognitive and neuroimaging predictors of future psychotic symptoms, as none are yet known. The greatest potential benefit of early diagnosis of a $22 q 11.2$ deletion would likely be to facilitate the recognition of the early stages of schizophrenia or another psychiatric illness, and promptly seeking expert help in diagnosis and effective treatment. ${ }^{9,78}$ Limiting the duration of untreated psychiatric illness is associated with better prognosis. ${ }^{101}$ Psychosis in an adolescent or young adult with 22q11.2DS should also be easier to diagnostically classify as schizophrenia in its early stages because of the significant association between these two elements, ${ }^{102}$ despite the potential additional diagnostic complexities that could be posed by comorbid mental retardation. ${ }^{103}$

\section{Schizophrenia in the molecular age}

Foreshadowed by the association with 22q11.2 deletions, there is further emerging evidence that multiple rare variants contribute significantly to the genetic vulnerability for schizophrenia. Other select genomic disorders caused by rare, recurring $\mathrm{CNV}$ represent emerging genetic subtypes of schizophrenia of growing clinical importance (Table 3). 
Table 3 The current established and emerging genetic subtypes of schizophrenia are characterized by large, rare, recurring copy number variation and variable expressivity

\begin{tabular}{|c|c|c|c|c|c|c|}
\hline $\begin{array}{l}\text { Genetic subtype } \\
\text { of schizophrenia }\end{array}$ & Established & \multicolumn{5}{|l|}{ Emerging } \\
\hline \multicolumn{7}{|l|}{ Genotype } \\
\hline Locus & $22 q 11.2$ & $|q 2| . \mid$ & $3 q 29$ & $15 q|1-q| 3$ & $15 q \mid 3.3$ & $|6 p| 1.2$ \\
\hline Copy number change & Loss & Loss & Loss & Gain $^{a}$ & Loss & Gain \\
\hline Typical size & $3.0 \mathrm{Mb}$ & $\mathrm{I} .4 \mathrm{Mb}$ & $1.6 \mathrm{Mb}$ & $6.0 \mathrm{Mb}$ & $1.5 \mathrm{Mb}$ & $0.6 \mathrm{Mb}$ \\
\hline \multicolumn{7}{|l|}{ Phenotype $^{\mathrm{b}}$} \\
\hline MIM number & $188400 / 192430$ & 612474 & 609425 & 608636 & 612001 & 611913 \\
\hline Schizophrenia & Yes & Yes & Yes & Yes & Yes & Yes \\
\hline Other psychiatric illnesses ${ }^{c}$ & Yes & Yes & Yes $^{d}$ & $Y_{e s}^{d}$ & Yes & Yes \\
\hline ASDs & Yes & Yes $^{\mathrm{d}}$ & Yes & Yes & Yes & Yes \\
\hline $\begin{array}{l}\text { Developmental } \\
\text { delay/mental retardation }\end{array}$ & Yes & Yes & Yes & Yes & Yes & Yes \\
\hline Seizures/epilepsy & Yes & Yes & $\mathrm{No}^{\mathrm{e}}$ & Yes & Yes & Yes \\
\hline Congenital anomalies $^{f}$ & Yes & Yes & Yes & $\mathrm{No}^{\mathrm{e}}$ & Yes & Yes \\
\hline References & See text $\mathrm{t}^{46}$ & $\begin{array}{l}64,159,163,164 \\
166,168,170,172 \\
173,175,249-254\end{array}$ & $\begin{array}{l}64,161,162 \\
166,255-261\end{array}$ & $\begin{array}{l}64,127,157, \\
159,160,180, \\
262-268\end{array}$ & $\begin{array}{l}64,159-161,164 \\
166,173,253 \\
254,269-278\end{array}$ & $\begin{array}{l}64,161,164,166, \\
173,182,253, \\
279-288\end{array}$ \\
\hline
\end{tabular}

Notes: a Originating on maternally derived chromosome; b there are no pathognomonic signs or symptoms, and the penetrance of each microdeletion or microduplication with respect to each component phenotype is incomplete; ' $m$ major depressive disorder, bipolar disorder, attention-deficit hyperactivity disorder/hyperactivity (unspecified),

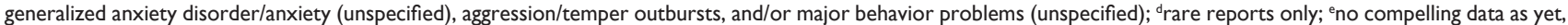
but there remain few detailed reports of the phenotype in individuals with this structural variant; 'cardiac anomalies, palatal anomalies (such as velopharyngeal insufficiency), skeletal abnormalities, and/or other major birth defects.

Abbreviations: ASDs, autism spectrum disorders; Mb, mega base pairs; MIM, Mendelian Inheritance in Man.

This encouraging progress comes after several decades of genome-wide and targeted molecular studies, representing essential, though largely unfruitful, tests of standard genetic hypotheses usually involving common variants at the level of nucleotide sequence (eg, single nucleotide polymorphisms [SNPs]) and DNA structure (eg, copy number polymorphisms [CNPs]). In retrospect, these studies were driven by genetically naïve expectations for schizophrenia. These included that there would exist (1) a single major locus, (2) common genetic variants of large effect, and (3) variants specific to schizophrenia (ie, not frequently associated with other conditions).

\section{Genome-wide linkage and association studies}

\section{Associations with schizophrenia}

Initially, several genome-wide linkage studies of multiply affected families identified regions where candidate genes for schizophrenia are likely to be. Some of these loci have been replicated and/or supported by meta-analyses, ${ }^{9,18,104-108}$ including 1q21-q23, 6p22, 8p21, and 13q32-q34. ${ }^{109-118}$ As expected, ${ }^{119}$ however, there are also negative studies of all loci. ${ }^{18,120-122}$ Despite a few highly significant findings that have led, for example, to identification of functional SNPs in candidate genes, ${ }^{123}$ one of the most important collective contributions of these studies has been the confirmation that there is no unifying single gene mutation for familial forms of schizophrenia.

In addition, there have now been several large-scale, case-control genome-wide association studies (GWAS) of schizophrenia using SNP-based microarray technology. Overall, this strategy, based on studying common SNPs, has proven to be relatively ineffective for the study of complex neuropsychiatric diseases, compared with the relative successes for auto immune diseases like diabetes and inflammatory bowel disease. ${ }^{124}$ Some of these GWAS failed to find significant evidence of association and/or have not replicated weak associations. ${ }^{125-129}$ Others have reported common sequence variants of very small effect, including several in the human leukocyte antigen (HLA) region (6p). ${ }^{130-137}$ The latter findings recall early studies of protein-based HLA polymorphisms. ${ }^{138,139}$ Meta-analysis using GWAS data from thousands of individuals with schizophrenia has revealed a few weak-effect associations, in the ZNF804A gene. ${ }^{140-143}$ GWAS of common structural variants such as CNPs, while fewer in number, have yielded comparable findings of nominal effect. ${ }^{127,144}$

GWAS using common SNPs and data on drug dosages and treatment response in schizophrenia (ie, pharmacogenomics studies) are reviewed elsewhere. ${ }^{145,146}$ These show modest results similar to those for diagnosis of schizophrenia, and broad clinical applications still represent more a dream than a 
reality; the family history with respect to treatment response remains arguably the best predictor of treatment efficacy and side effects. ${ }^{147}$ Findings from thousands of targeted candidate gene association studies of schizophrenia using individual SNPs (and, occasionally, specific rare sequence variants), catalogued online in the SzGene database ${ }^{148}$ (www.szgene. org) and the database of Genotypes and Phenotypes (www. ncbi.nlm.nih.gov/gap), are either negative altogether or sporadically positive without replication and/or positive but with modest effect size. None are associated with a relative risk for schizophrenia anything approaching that of the $\varepsilon 4$ variant of the APOE gene relative risk for Alzheimer disease (Table 1). ${ }^{9}$ Taken together, the GWAS and targeted association study results conclusively indicate there are no common genetic variants of large effect for schizophrenia.

\section{Clinical relevance}

Although linkage approaches and GWAS of common variants have yielded a collection of several dozen candidate genes, the individual effect sizes of associated variants are modest. Mutation testing in these genes has no role in the clinic at this time. Larger and larger sample sizes have ensured that variants of smaller and smaller effect may be detected. Importantly, a GWAS design lacks the power to detect rare sequence variants of large effect, and it is rare variants that may collectively play a major role in the etiology of schizophrenia. ${ }^{124}$ While preliminary findings from the first whole exome sequencing studies in schizophrenia are solely in the realm of scientific discovery at this time, they provide evidence in support of a de novo mutational paradigm at the sequence level. ${ }^{149,150}$ In time, these studies may provide clinically relevant findings. However, the most notable evidence today for clinically important rare genetic variants in schizophrenia comes from studies of $\mathrm{CNV}$ - that is, structural genomics.

\section{Rare copy number variation and emerging genetic subtypes}

The discovery that there is substantial structural genomic variation in the human genome that contributes to both normal variation and to susceptibility for disease is one of the major scientific advances in recent years..$^{5,64,151-155}$ Consistent with early reports of the association of schizophrenia with rare microscopically visible chromosomal abnormalities ${ }^{156}$ and the established association with 22q11.2 deletions, ${ }^{43,66,67,69}$ there is now substantial evidence for the importance of diverse rare structural variants in causing schizophrenia. ${ }^{3,5}$ These structural variants are mainly comprised of specific examples of large (eg, $>500 \mathrm{~kb}$ ) CNV that are consistently enriched in schizophrenia samples, and absent or extremely uncommon (ie, "rare") in control populations.

\section{Associations with schizophrenia}

Following the discovery of $22 \mathrm{q} 11.2$ deletions in schizophrenia, the next tier of large, rare CNV findings includes a set of emerging genetic subtypes of schizophrenia (Table 3$){ }^{3}$ In contrast to $22 q 11.2 \mathrm{DS}$, the epidemiology and basic genetic parameters such as penetrance and expression remain uncertain for these genomic disorders, and there has been little to no study of the dosage-sensitive genes that may cause the associated phenotypes ${ }^{64}$ Collectively, however, this second tier of CNV may be as or more common in schizophrenia than $22 q 11.2$ deletions. ${ }^{3,5}$ Those variants identified to date include large $(>500 \mathrm{~kb})$, rare, recurring (flanked by segmental duplications), hemizygous losses (deletions) and gains (duplications) at several loci (Table 3). All involve numerous genes and are consistently identified in largescale case-control CNV studies of schizophrenia, albeit each individually at apparently low prevalence. A recent review has suggested pooled odds ratios for schizophrenia of 8 or higher for four of these five genomic disorders, ${ }^{5}$ and for 15q11-q13 duplications of maternal origin, an initial report based on four cases suggested an odds ratio for schizophrenia of 7.3. ${ }^{157}$ As with $22 \mathrm{q} 11.2$ deletions, ${ }^{3}$ these rare structural variants may be expressed as other psychiatric illnesses and/or developmental conditions, such as autism spectrum disorders (ASDs) and epilepsy (Table 3). On the other hand, the few studies of rare CNV in bipolar disorder indicate little overlap of these forms of schizophrenia with this major mood disorder. ${ }^{5,158}$ This would be consistent with the historical clinical separation of schizophrenia and bipolar disorder based on presentation, course, and outcome, and the perhaps less "neurodevelopmental" nature of bipolar disorder. The variability of expression of $22 \mathrm{q} 11.2$ deletions and these other rare structural variants is shining new light on schizophrenia and on the genetically related spectrum of neuropsychiatric disorders. ${ }^{3}$ There are also other potential susceptibility factors for schizophrenia of likely smaller effect (Table 4), ${ }^{5}$ such as hemizygous deletions at $15 q 11.2^{159-164}$ and $17 \mathrm{q} 12,{ }^{162,165}$ and duplications at $1 \mathrm{q} 21.1^{159,164,166}$ and 16p13.11. ${ }^{160,167}$ These appear to be similarly or more variable in their expression and less penetrant with respect to schizophrenia, or indeed any major phenotype, than $22 \mathrm{q} 11.2$ deletions and the five emerging genetic subtypes. ${ }^{64,168-179}$ All await more detailed study, especially of expression in adults. 
Table 4 outlines some of the many remaining issues with respect to clinical translation for possible genetic subtypes of schizophrenia. For instance, there are limited or inconsistent data on CNV inheritance status or comorbidity in most of the existing studies, and numerous systematic methodological issues that complicate the assessment of prevalence and penetrance..$^{3,180}$ Truly inclusive population-based prevalence samples of schizophrenia (eg, community catchments) are difficult to obtain, and many of the initial large case-control studies may have implicitly or explicitly excluded subjects with dysmorphic features, birth defects, learning difficulties, and/or known syndromes. ${ }^{3}$ Such systematic ascertainment biases in sample collection for large-scale case-control studies suggest that the prevalence of genomic disorders in schizophrenia may be underestimated. As an example, the expected prevalence of $22 \mathrm{q} 11.2$ deletions in schizophrenia is about $1 \%,{ }^{65,181}$ but a pooled estimated prevalence based on large consortium-based case-control studies is approximately $0.3 \% .{ }^{5}$ There are also few data concerning fundamental issues such as the possible effects of sex, ethnicity (most studies to date have involved Caucasians), or sampling from genetic isolates. Nonetheless, this initial wave of genome-wide studies of CNV provides replicated associations of schizophrenia with specific rare variants. This supports a more general mutational mechanism involving large rare CNV that substantially elevate risk for schizophrenia, especially more developmental forms of the disease. ${ }^{3,182}$

\section{Neurodevelopmental implications}

Notably, many of the structural variants associated with schizophrenia implicate a dosage effect of neurodevelopmental genes involved with neuronal proliferation, migration, or synapse formation. ${ }^{2,182}$ Although there are few studies that have examined age at onset of schizophrenia, ${ }^{166}$ it may be that



Figure I Neurodevelopmental model of schizophrenia, informed by new molecular genetic discoveries. One or more transmitted or de novo sequence or structural mutations, involving one or more genes, and acting individually or interactively, is proposed as the initial causal event. The pathway from genotype to phenotype is formulated as a dynamic process beginning at or before conception, and involving gene expression (including, but not limited to, protein activity) and interaction with normal brain development and neuronal plasticity mechanisms, and likely multiple other genetic and non-genetic factors. Different phenotypic endpoints are possible, and specific factors that dictate variable expression of ostensibly the same genetic loading are largely unknown and may be variant-specific. These resulting phenotypes could include clinically diagnosable schizophrenia, other psychiatric illnesses, other conditions including disorders of development, or no detectable expression. For example, a $22 q 1$ I.2 deletion (yellow structural variant) may be expressed as schizophrenia and/or a related psychiatric disorder and/or another developmental disorder (yellow stars).

Note: Adapted from AS Bassett, EW Chow, S O'Neill, LM Brzustowicz, Genetic insights into the neurodevelopmental hypothesis of schizophrenia, Schizophrenia Bulletin, 200I, 27, 3, pp. 4I7-430, by permission of Oxford University Press. ${ }^{35}$

Abbreviation: CNV, copy number variation. 
rare CNV have a greater impact on such genes in individuals with younger onset (eg, childhood, age $<12$ years) compared with onset at older ages. ${ }^{182}$ This would be consistent with a previously reported greater prevalence of chromosomal abnormalities and 22q11.2 deletions in childhood-onset schizophrenia. ${ }^{183}$ Several other lines of evidence, including brain imaging, premorbid clinical signs, and associations with minor dysmorphic features, have previously indicated that early changes in neurodevelopment may be involved in the pathogenesis of schizophrenia..$^{2,35,184}$ The current genetic neurodevelopmental model of the etiopathogenesis of schizophrenia (Figure 1) has important consequences with respect to the potential for pre-symptomatic prediction and, ultimately, attenuation, delay, or prevention of psychosis, as well as present-day genetic counseling (outlined below).

\section{Clinical relevance}

Use of 22q11.2DS as the benchmark for clinical applicability of molecular genetics in schizophrenia highlights the gaps that currently exist at the level of translating recent genetic results involving other large rare CNV to inform clinical management of patients (Table 4). Optimism about eventual direct benefits for patients and their families stems from the observations that effect sizes are generally large and that the spectrum of disorders involved in variable expression may tend to be multisystem and/or developmental in nature. This may be related to the multiple genes usually involved in large CNV, and in turn suggests that penetrance for any observable phenotype, as opposed to schizophrenia per se, will be fairly high. Meaningful prediction of some associated conditions would then be possible, creating opportunities for anticipatory care and improved medical management, as already exist for 22q11.2DS. ${ }^{3}$ Eventually, such genetic variants may also assist in diagnostic subtyping of schizophrenia.

Psychiatric disorders in general appear to have a poorly understood, nuanced connection to the various associated structural variants. ${ }^{153}$ Determinants of disease specificity may be other, perhaps more common, genetic, epigenetic, stochastic, and/or environmental modifiers. There has been little research as yet on such additional factors (Table 4). ${ }^{185}$ Likely the research that will have the most clinical impact will involve unbiased sampling, family studies, and detailed study of the variable expression and natural history of individual variants. This will in turn facilitate specific care recommendations and prediction of comorbidities, and eventually prognosis and drug response (Table 4$).{ }^{3}$ To date, in order to gain sample sizes sufficient to detect signals in genetically heterogeneous populations, many researchers have sacrificed: (1) detailed phenotyping of the probands, (2) the ability to return to individual participants after analyses, and (3) the familial context necessary to assess de novo status and segregation patterns. These features represent, from a clinician's point of view, unfortunate consequences of the study design of much of the large-scale genetics research conducted thus far in the twenty-first century. The longstanding practice of DNA sample anonymity, and other formal barriers between research participation and clinical care, is more and more at odds with a conflicting "duty to warn" in this new era of molecular medicine, where actionable and clinically relevant information is increasingly likely to be obtained. ${ }^{186,187}$ Researchers, clinicians, and genetic counselors must begin to consider new strategies for when and how to routinely return to genotypic information and subsequently inform research participants and their clinicians of medically pertinent findings, keeping in mind that the interpretation of any particular variant is subject to change as new data accrues.

Lack of data on potential utility at this time, especially given limited resources, suggests that clinical genome-wide microarray testing is not yet justified for individuals with schizophrenia, except for the minority with syndromic and/or neurodevelopmental features such as mental retardation or multiple congenital anomalies. ${ }^{3,61,65}$ Similarly, calls for routine targeted clinical testing on the basis of a single study where penetrance and information about expression remain unknown (eg, 7q36.3 duplications of various sizes implicating the VIPR2 gene $^{188}$ ) appear dangerously premature. The effectiveness of personal genomic information in tailoring interventions and improving health outcomes has not yet been convincingly demonstrated for emerging genetic subtypes of schizophrenia, nor for susceptibility factors that may be relevant for this complex disease. There are also limited to no data with respect to the ethical, legal, social, and economic implications of widespread personal genomic testing. ${ }^{189}$ As for other diseases like ASDs, ${ }^{61,190}$ careful consideration and professional consensus are needed to decide how to apply such genomic knowledge in clinical practice. Use of wellrecognized standards and guidelines for clinical genetic testing, such as the ACCE Model Process for Evaluating Genetic Tests (available from: www.cdc.gov/genomics/ gtesting/ACCE/), may be helpful in this regard. Their application quickly exposes the many gaps in our fundamental knowledge base with respect to the clinical and analytic validity, and clinical utility, of genetic testing for most $\mathrm{CNV}$ in schizophrenia, particularly compared with other diseases 
Table 4 Pathway to clinical utility for copy number variation and genomic disorders associated with schizophrenia (as of 20II)

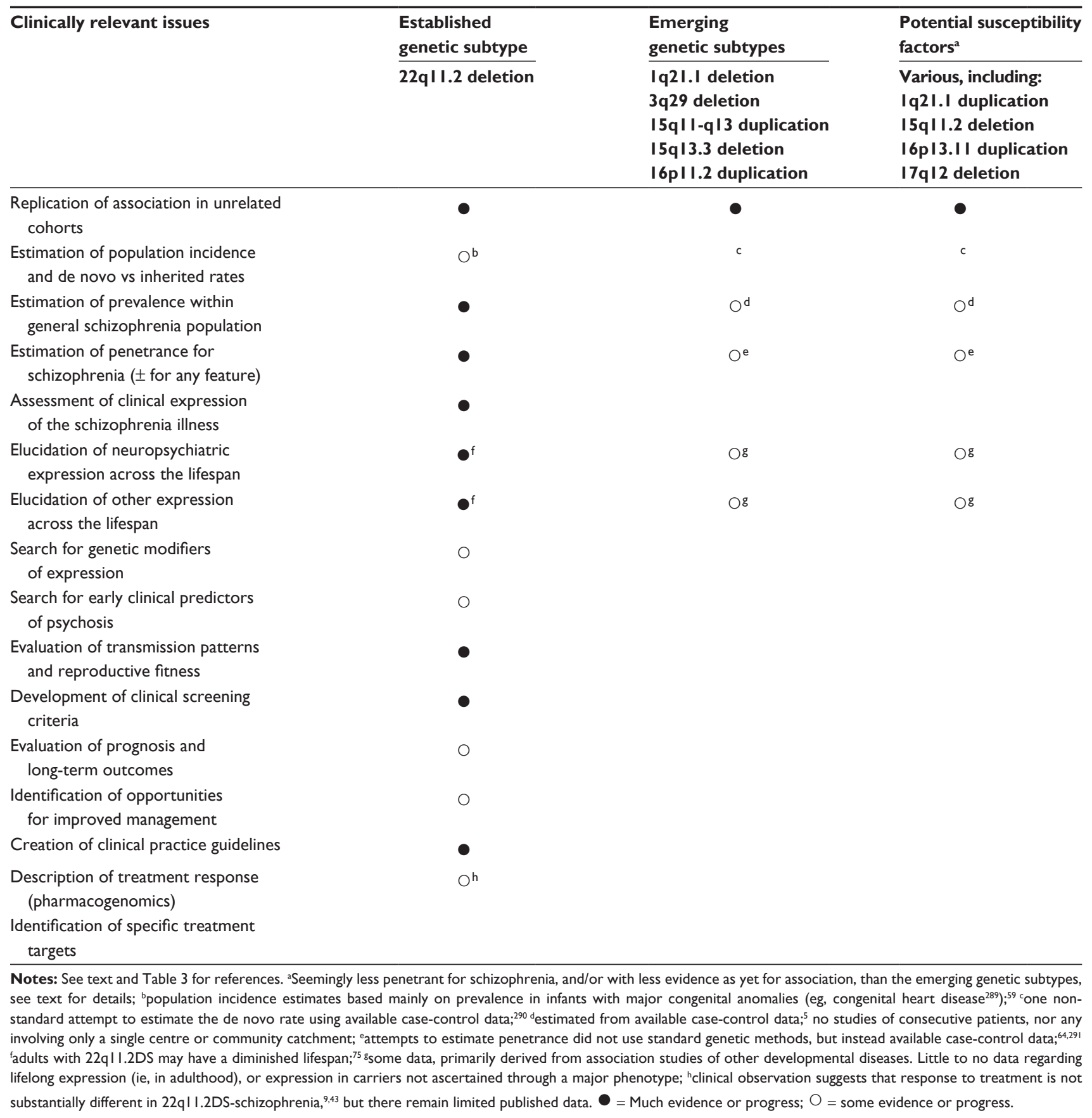

and genetic variants such as breast/ovarian cancer and $B R C A 1$ and $B R C A 2$ mutations. ${ }^{191}$

\section{Genetic risk and counseling issues}

Genetic counseling for schizophrenia largely continues to focus on recurrence risk based on family history, but recent molecular genetic discoveries are now having a significant impact in specific cases. Post-onset (ie, phenotype first), the identification and disclosure of a well-established genetic variant (eg, a 22q11.2 deletion) that is strongly associated with a stigmatized illness like schizophrenia may be highly valued by the patient and family for its explanatory value. ${ }^{186,192}$ Such variants also provide the potential to inform reproductive decision making, including the possible availability of prenatal detection. ${ }^{3}$ Even in the absence of such genetic variants, genetic counseling for schizophrenia may still represent an informative and therapeutic intervention. However, there are limited empiric data about potential benefits at present. 


\section{Genomic disorders and genetic subtypes}

Identifying genetic subtypes of schizophrenia offers new possibilities with respect to recurrence risk prediction. In the case of an individual with 22q11.2DS-schizophrenia and no other affected relatives (including the spouse or partner), for example, knowledge of the proband's 22q11.2 deletion bifurcates the risk scenario. Transmission of the 22q11.2 deletion would imply a recurrence risk for schizophrenia of approximately $20 \%-25 \%$ in each offspring, whereas a failure to transmit the deletion would theoretically decrease that risk to the standard population rate $(\sim 1 \%)$. With no knowledge about the 22q11.2 deletion status, offspring would have an a priori averaged (though individually far less informative) recurrence risk for schizophrenia that is comparable to the standard empiric recurrence risk of $13 \%{ }^{20,147}$ Also, identification of a de novo 22q11.2 deletion, or other putatively causal de novo $\mathrm{CNV}$, in an individual with schizophrenia would be expected to lower the recurrence risk for siblings and nieces/nephews to nearly the population rate. ${ }^{10}$ We note from experience that for schizophrenia the risk of recurrence in siblings and nieces/nephews is the dominant concern expressed in most genetic counseling sessions, given the significantly decreased reproductive fitness associated with schizophrenia and concomitantly few direct offspring. ${ }^{57,193,194}$

As new diagnoses of specific genomic disorders and increasing evidence for their involvement in schizophrenia flood clinical practice, the need for more psychiatric genetic counseling research and training will be increasingly apparent. First, the association of specific large rare CNV with schizophrenia, as outlined above (Tables 3 and 4), effectively means that incidental predictive "genetic testing" for schizophrenia is now a reality of clinical practice, because of the use of clinical microarrays as a first-tier diagnostic test for developmental delay/mental retardation, multiple congenital anomalies (even in utero), or ASD. ${ }^{10,61}$ Proposed benefits and disadvantages of predictive testing are discussed elsewhere. ${ }^{147,195,196}$ Genetic counselors, however, may be reluctant to disclose the possibility of psychotic illness to parents even in the context of well-established risk factors such as 22q11.2 deletions. Stigma, ${ }^{197}$ lack of knowledge about the illness and its treatment, and concerns about generating anxiety ${ }^{79}$ may play a role in deferral or non-disclosure, ${ }^{198}$ despite some evidence that opportunities to anticipate and prepare for such an illness would have been valued by the parents. ${ }^{186}$ Second, genetic counseling of the adolescent and adult patients themselves may be complicated by cognitive impairments and/or psychiatric symptoms. ${ }^{147,199}$ There are surprisingly few empirical studies of the optimal content and process, and of the effectiveness and ensuing outcomes, of genetic counseling in these instances, ${ }^{199,200}$ even for well-recognized genomic disorders like 22q11.2DS ${ }^{57}$ or Williams syndrome. ${ }^{201}$

On the other hand, clinical microarrays also give results unrelated to current genomic disorders and about which there is much uncertainty with respect to interpretation. Today, proposed workflow algorithms for determining pathogenicity are likely to label most individual CNV identified, other than the relatively established like those underlying 22q11.2DS and other genomic disorders, as "variants of unknown significance" or "VOUS." ${ }^{153,202}$ This is of particular concern for smaller (atypical) rare $\mathrm{CNV}$ at loci that may be associated with emerging genetic subtypes of, or possible susceptibility factors for, schizophrenia. The nature of schizophrenia poses additional challenges. For example, parents of adult patients are less likely to be available for testing to determine de novo/inherited status, and patients may be poor historians with respect to medical and/or family history. Clinical interpretation of many CNV findings will thus remain a major challenge for the foreseeable future.

\section{Familial schizophrenia}

Individuals from multiplex families arguably have the greatest need for risk prediction and genetic counseling. However, empiric recurrence risk figures cannot be quantitatively modified to account for multiple affected relatives or a bilineal (ie, maternal and paternal) family history. ${ }^{147,203}$ The sole exceptions relate to the situations where both parents, or one parent and one sibling, are affected, for which some recurrence risk data are available. ${ }^{9,147,204}$ There is also no ability to adjust risk to take into account relatives with schizophrenia spectrum conditions and/or other neuropsychiatric diseases. ${ }^{147,203}$ Also, unlike in Huntington disease before mutation identification, ${ }^{9,205,206}$ knowledge of linkage or association information where it exists for individual families cannot be meaningfully incorporated into illness prognostication, given the modest effect size of alleles identified.

As for any individual with schizophrenia, clinicians should be aware of features consistent with testable conditions like 22q11.2DS. However, 22q11.2 deletions are less likely to be co-segregating with schizophrenia in multiply affected families, as they are associated with a strong negative selective pressure..$^{57}$ Other large rare CNV associated with schizophrenia, for example, microduplications not associated with multisystem/syndromic features, ${ }^{157,180}$ may have less effect on reproductive fitness and thus a higher 
likelihood of contributing to the burden of illness in multiply affected families, though this remains to be shown. There is growing empirical ${ }^{207}$ and theoretical ${ }^{208,209}$ evidence that, as for Parkinson disease,${ }^{210}$ familial and "sporadic" schizophrenia may not be molecularly distinct entities. This underscores the need for a greater focus in future studies on both the inheritance status of genetic variants shown to be associated with schizophrenia, and on the extent of co-segregation of these variants with other neuropsychiatric illness and developmental conditions within families.

\section{Idiopathic schizophrenia}

Often overlooked in our collective enthusiasm for the promise of new genetic discoveries are the sobering realizations that the vast majority of cases of schizophrenia are "idiopathic" and that, as for most conditions, ${ }^{211}$ family history remains the cornerstone for individualized disease prediction. When the schizophrenia is not a syndromic form of the illness, ${ }^{9}$ of genetically testable origin, ${ }^{61}$ or originating in the context of a multiplex family, patients and their relatives are unlikely to be seen by a genetics professional unless presented with an unrelated concern. ${ }^{147}$ Much has been written and repeated over the past several decades about the optimal content and process of "multifactorial" genetic counseling, ,147,196,204,212-214 despite low rates of genetic counseling referrals ${ }^{215}$ and a continued scarcity of evidence in support of the desirability ${ }^{216}$ or effectiveness ${ }^{217}$ of the genetic counseling intervention. To assess these key issues, and also prepare for the growing role of personalized molecular genetic information, there is an urgent need for data-driven reports of the genetic counseling of patients with idiopathic schizophrenia and their relatives.

Recent advances in schizophrenia genetics may still be germane to contemporary genetic counseling however, even in the absence of personalized application. For example, presenting schizophrenia to consultands as a neurodevelopmental disorder (Figure 1), ${ }^{35}$ with psychosis as a later stage manifestation often preceded by a prodromal period, ${ }^{2}$ has the potential to further modify false beliefs that upbringing, lifestyle decisions, or other "triggers"204 are either necessary or sufficient to cause an illness that otherwise would not have developed. Proof that de novo mutations play an important causal role in some cases may help in dispelling a popular misconception ${ }^{218}$ that "genetic" and "inherited" are synonymous terms. Especially in the absence of an affected first- or second-degree ancestor, de novo mutation is a highly plausible theory of causation that may decrease a sense of family blame or shame. Finally, presenting evidence for genetic and epigenetic differences between monozygotic twins can help to explain discordant twin pairs without needing to resort to the unsupported assumption of powerful environmental factors in these rare cases. ${ }^{219-222}$ The role of independent environmental factors ${ }^{29}$ may be less, and that of gene-environment interactions ${ }^{25,223,224}$ and stochastic effects $^{225,226}$ may be greater, than initially supposed.

As yet, the full "risk architecture" of schizophrenia, and the extent to which risk factors may be modifiable, is unknown. ${ }^{2}$ With respect to idiopathic schizophrenia, there is a forced reliance on family history and associated crude empiric recurrence risks, unmodified quantitatively by any other clinical or demographic variables. ${ }^{203}$ Few attempts have been made to update or validate these recurrence risks, despite the potential increase in the proportion of individuals with schizophrenia who partner with someone else with schizophrenia (ie, assortative mating), ${ }^{227}$ new conceptualizations of the genetically relevant schizophrenia spectrum, ${ }^{3}$ and increasing opportunities for molecular characterization. Initial attempts to generate a "risk score" from multiple variants with weak association with schizophrenia may be promising avenues for future research, ${ }^{131,228,229}$ but are not yet meaningful in a clinical genetic counseling context. In addition, the factors of primary interest in genetic counseling (ie, those that increase individual recurrence risk substantially) do not necessarily have much effect on average risk, the primary focus of most retrospective studies of schizophrenia, and vice versa. ${ }^{230}$ Partial risk prediction as afforded by proven moderate to high penetrance variants such as 22 q11.2 deletions may be the best case scenario. There are likely to be fundamental limits on precise individualized genetic risk prediction due to the complex architecture of common traits, including common variants of very small effect, rare variants that cannot be fully enumerated, and complex epistatic interactions, as well as stochastic and possible environmental factors. ${ }^{231}$ The potential "added value" of genome-wide data (eg, derived from next-generation sequencing) in tailoring risk estimates would also need to be weighed against many other factors. These include the cost of, and expertise needed for, the molecular analysis (which is still prohibitive for widespread use, particularly in publicly funded health care systems) and the interpretation of results (as great or greater than molecular analytic costs, and less likely to decrease over time). ${ }^{231}$ Such barriers will impede widespread application of new genetic technologies in clinical practice more generally for the foreseeable future. Personal genome sequencing as a single universal genetic test that is cost-effective and of broadly applicable clinical utility remains a distant, though much wished for, prospect. ${ }^{232}$ 


\section{Conclusion}

Schizophrenia is a complex neuropsychiatric disease with documented clinical and genetic heterogeneity, and little is known about the associated pathophysiology apart from strong evidence for neurodevelopmental origins. The elucidation of specific causes and mechanisms for schizophrenia that is beginning to be derived from advances in molecular genetics and related research promises to help many families afflicted with this illness. However, much work needs to be done to move the recent surge of genetic research discoveries into the clinic. In particular, specific large rare structural variants (CNV) have been convincingly implicated in targeted studies over two decades (with respect to 22q11.2 deletions) and more recently in several large-scale genome-wide casecontrol studies of schizophrenia. Clinical interpretation of most individual loci remains unclear as yet because the associated epidemiology and basic genetic parameters (such as penetrance and expression) are not yet well characterized. For now, 22q11.2 deletions represent the cutting-edge of clinically applicable molecular genetics in schizophrenia. New opportunities in risk prediction and genetic counseling are exciting avenues for future research.

\section{Acknowledgments}

The authors thank Sean Bekeschus for his assistance with aesthetic design of the figure. This work was supported by Canadian Institutes of Health Research grants (MOP-97800, MOP-111238, MOP-53216), a Vanier Canada Graduate Scholarship (GC), and a Canada Research Chair in Schizophrenia Genetics and Genomic Disorders (ASB).

\section{Disclosure}

The authors have no actual or potential conflicts of interest to disclose in this work.

\section{References}

1. Where next with psychiatric illness? Nature. 1988;336(6195):95-96.

2. Insel TR. Rethinking schizophrenia. Nature. 2010;468(7321):187-193.

3. Bassett AS, Scherer SW, Brzustowicz LM. Copy number variations in schizophrenia: critical review and new perspectives on concepts of genetics and disease. Am J Psychiatry. 2010;167(8):899-914.

4. Gejman PV, Sanders AR, Kendler KS. Genetics of schizophrenia: new findings and challenges. Annu Rev Genomics Hum Genet. 2011;12:121-144.

5. Hochstenbach R, Buizer-Voskamp JE, Vorstman JA, Ophoff RA. Genome arrays for the detection of copy number variations in idiopathic mental retardation, idiopathic generalized epilepsy and neuropsychiatric disorders: lessons for diagnostic workflow and research. Cytogenet Genome Res. 2011;135(3-4):174-202.

6. Kim Y, Zerwas S, Trace SE, Sullivan PF. Schizophrenia genetics: where next? Schizophr Bull. 2011;37(3):456-463.

7. Kirov G. The role of copy number variation in schizophrenia. Expert Rev Neurother. 2010;10(1):25-32.
8. Rodriguez-Murillo L, Gogos JA, Karayiorgou M. The genetic architecture of schizophrenia: new mutations and emerging paradigms. Annu Rev Med. 2012;63:63-80.

9. Bassett AS, Chow EWC, Hodgkinson KA. Genetics of schizophrenia and psychotic disorders. In: Smoller JW, Rosen Sheidley B, Tsuang MT, editors. Psychiatric Genetics: Applications in Clinical Practice. Arlington: American Psychiatric Publishing, Inc; 2008:99-130.

10. Collier DA, Vassos E, Holden S, Patch C, McGuire P, Lewis C. Advances in the genetics of schizophrenia: will high-risk copy number variants be useful in clinical genetics or diagnostics? F1000 Med Rep. 2009;1:61.

11. Moreno-De-Luca D, Cubells JF. Copy number variants: a new molecular frontier in clinical psychiatry. Curr Psychiatry Rep. 2011; 13(2):129-137.

12. Mueser KT, Jeste DV. Clinical Handbook of Schizophrenia. New York: Guilford Press; 2008.

13. Brzustowicz LM, Bassett AS. Phenotype matters: the case for careful characterization of relevant traits. Am J Psychiatry. 2008;165(9): 1096-1098.

14. Harper PS. A Short History of Medical Genetics. New York: Oxford University Press; 2008

15. Cannon TD, Kaprio J, Lonnqvist J, Huttunen M, Koskenvuo M. The genetic epidemiology of schizophrenia in a Finnish twin cohort. A population-based modeling study. Arch Gen Psychiatry. 1998; 55(1):67-74.

16. Cardno AG, Gottesman II. Twin studies of schizophrenia: from bowand-arrow concordances to star wars $\mathrm{Mx}$ and functional genomics. Am J Med Genet. 2000;97(1):12-17.

17. Kendler KS, Diehl SR. The genetics of schizophrenia: a current, geneticepidemiologic perspective. Schizophr Bull. 1993;19(2):261-285.

18. Kirov G, O'Donovan MC, Owen MJ. Finding schizophrenia genes. J Clin Invest. 2005;115(6):1440-1448.

19. Gottesman II, Shields J, Hanson DR. Schizophrenia, the Epigenetic Puzzle. New York: Cambridge University Press; 1982.

20. Gottesman II, Wolfgram DL. Schizophrenia Genesis: The Origins of Madness. New York: Freeman; 1991.

21. Kendler KS, Gruenberg AM, Tsuang MT. Psychiatric illness in firstdegree relatives of schizophrenic and surgical control patients. A family study using DSM-III criteria. Arch Gen Psychiatry. 1985;42(8): 770-779.

22. Lowing PA, Mirsky AF, Pereira R. The inheritance of schizophrenia spectrum disorders: a reanalysis of the Danish adoptee study data. Am J Psychiatry. 1983;140(9):1167-1171.

23. Moldin SO, Gottesman II. At issue: genes, experience, and chance in schizophrenia - positioning for the 21st century. Schizophr Bull. 1997;23(4):547-561.

24. Tienari PJ, Wynne LC. Adoption studies of schizophrenia. Ann Med. 1994;26(4):233-237.

25. AbdelMalik P, Husted J, Chow EW, Bassett AS. Childhood head injury and expression of schizophrenia in multiply affected families. Arch Gen Psychiatry. 2003;60(3):231-236

26. Byrne M, Browne R, Mulryan N, et al. Labour and delivery complications and schizophrenia. Case-control study using contemporaneous labour ward records. Br J Psychiatry. 2000;176:531-536.

27. Henquet C, Di Forti M, Morrison P, Kuepper R, Murray RM. Geneenvironment interplay between cannabis and psychosis. Schizophr Bull. 2008;34(6):1111-1121.

28. McGuffin P, Asherson P, Owen M, Farmer A. The strength of the genetic effect. Is there room for an environmental influence in the aetiology of schizophrenia? Br J Psychiatry. 1994;164(5):593-599.

29. Matheson SL, Shepherd AM, Laurens KR, Carr VJ. A systematic metareview grading the evidence for non-genetic risk factors and putative antecedents of schizophrenia. Schizophr Res. 2011;133(1-3):133-142.

30. Moore TH, Zammit S, Lingford-Hughes A, et al. Cannabis use and risk of psychotic or affective mental health outcomes: a systematic review. Lancet. 2007;370(9584):319-328.

31. Tienari P. Implications of adoption studies on schizophrenia. $\mathrm{Br} J$ Psychiatry Suppl. 1992;18:52-58. 
32. Wahlberg KE, Wynne LC, Oja H, et al. Gene-environment interaction in vulnerability to schizophrenia: findings from the Finnish Adoptive Family Study of Schizophrenia. Am J Psychiatry. 1997;154(3):355-362.

33. Gottesman II, Bertelsen A. Confirming unexpressed genotypes for schizophrenia. Risks in the offspring of Fischer's Danish identical and fraternal discordant twins. Arch Gen Psychiatry. 1989; 46(10):867-872.

34. Kringlen E, Cramer G. Offspring of monozygotic twins discordant for schizophrenia. Arch Gen Psychiatry. 1989;46(10):873-877.

35. Bassett AS, Chow EW, O’Neill S, Brzustowicz LM. Genetic insights into the neurodevelopmental hypothesis of schizophrenia. Schizophr Bull. 2001;27(3):417-430.

36. Bassett AS, Chow EW, Waterworth DM, Brzustowicz L. Genetic insights into schizophrenia. Can J Psychiatry. 2001;46(2):131-137.

37. Prasad KM, Talkowski ME, Chowdari KV, McClain L, Yolken RH Nimgaonkar VL. Candidate genes and their interactions with other genetic/environmental risk factors in the etiology of schizophrenia. Brain Res Bull. 2010;83(3-4):86-92.

38. Risch N. Linkage strategies for genetically complex traits. I. Multilocus models. Am J Hum Genet. 1990;46(2):222-228.

39. Phillips PC. Epistasis - the essential role of gene interactions in the structure and evolution of genetic systems. Nat Rev Genet. 2008;9(11): 855-867.

40. Book JA. Schizophrenia as a gene mutation. Acta Genet Stat Med. 1953; 4(2-3):133-139

41. Penrose LS. Mutation in man. Acta Genet Stat Med. 1956;6(2) 169-182.

42. McClellan JM, Susser E, King MC. Schizophrenia: a common disease caused by multiple rare alleles. Br J Psychiatry. 2007;190:194-199.

43. Bassett AS, Chow EW. Schizophrenia and 22q11.2 deletion syndrome Curr Psychiatry Rep. 2008;10(2):148-157.

44. McDonald-McGinn DM, Zackai EH. The history of the 22q11.2 deletion [webpage on the Internet]. Philadelphia, PA: Clinical Genetics CenterThe Children's Hospital of Philadelphia; nd. Available from: http:// www.cbil.upenn.edu/VCFS/history.html. Accessed January 4, 2012

45. Shprintzen RJ, Goldberg R, Golding-Kushner KJ, Marion RW Late-onset psychosis in the velo-cardio-facial syndrome. Am J Med Genet. 1992;42(1):141-142.

46. Bassett AS, McDonald-McGinn DM, Devriendt K, et al. Practical guidelines for managing patients with $22 \mathrm{q} 11.2$ deletion syndrome. J Pediatr. 2011;159(2):332-339 e1.

47. Karayiorgou M, Simon TJ, Gogos JA. 22q11.2 microdeletions: linking DNA structural variation to brain dysfunction and schizophrenia. Nat Rev Neurosci. 2010;11(6):402-416.

48. Philip N, Bassett A. Cognitive, behavioural and psychiatric phenotype in 22q11.2 deletion syndrome. Behav Genet. 2011;41(3):403-412.

49. Sandrin-Garcia P, Abramides DV, Martelli LR, Ramos ES, RichieriCosta A, Passos GA. Typical phenotypic spectrum of velocardiofacial syndrome occurs independently of deletion size in chromosome 22q11.2. Mol Cell Biochem. 2007;303(1-2):9-17.

50. Weksberg R, Stachon AC, Squire JA, et al. Molecular characterization of deletion breakpoints in adults with 22q11 deletion syndrome. Hum Genet. 2007;120(6):837-845.

51. Edelmann L, Pandita RK, Morrow BE. Low-copy repeats mediate the common 3-Mb deletion in patients with velo-cardio-facial syndrome. Am J Hum Genet. 1999;64(4):1076-1086.

52. Stankiewicz P, Lupski JR. Genome architecture, rearrangements and genomic disorders. Trends Genet. 2002;18(2):74-82.

53. Bassett AS, Marshall CR, Lionel AC, Chow EW, Scherer SW. Copy number variations and risk for schizophrenia in 22q11.2 deletion syndrome. Hum Mol Genet. 2008;17(24):4045-4053.

54. Cohen E, Chow EW, Weksberg R, Bassett AS. Phenotype of adults with the 22q11 deletion syndrome: A review. Am J Med Genet. 1999; 86(4):359-365.

55. Digilio MC, Angioni A, De Santis M, et al. Spectrum of clinical variability in familial deletion 22q11.2: from full manifestation to extremely mild clinical anomalies. Clin Genet. 2003;63(4): 308-313.
56. McDonald-McGinn DM, Tonnesen MK, Laufer-Cahana A, et al. Phenotype of the 22q11.2 deletion in individuals identified through an affected relative: cast a wide FISHing net! Genet Med. 2001; 3(1):23-29.

57. Costain G, Chow EW, Silversides CK, Bassett AS. Sex differences in reproductive fitness contribute to preferential maternal transmission of 22q11.2 deletions. J Med Genet. 2011;48(12):819-824.

58. Lupski JR. Genomic disorders ten years on. Genome Med. 2009; 1(4):42.

59. Kobrynski LJ, Sullivan KE. Velocardiofacial syndrome, DiGeorge syndrome: the chromosome 22q11.2 deletion syndromes. Lancet. 2007;370(9596):1443-1452.

60. McDonald-McGinn DM, Sullivan KE. Chromosome 22q11.2 deletion syndrome (DiGeorge syndrome/velocardiofacial syndrome). Medicine (Baltimore). 2011;90(1):1-18.

61. Miller DT, Adam MP, Aradhya S, et al. Consensus statement: chromosomal microarray is a first-tier clinical diagnostic test for individuals with developmental disabilities or congenital anomalies. Am J Hum Genet. 2010;86(5):749-764.

62. Tokuyasu TA, Cotter PD, Segraves R, et al. Detection of single clone deletions using array $\mathrm{CGH}$ : identification of submicroscopic deletions in the $22 \mathrm{q} 11.2$ deletion syndrome as a model system. Am J Med Genet A. 2007;143A(9):925-932.

63. Bassett AS, Chow EW, Husted J, et al. Clinical features of 78 adults with 22q11 Deletion Syndrome. Am J Med Genet A. 2005;138(4):307-313.

64. Cooper GM, Coe BP, Girirajan S, et al. A copy number variation morbidity map of developmental delay. Nat Genet. 2011;43(9):838-846.

65. Bassett AS, Costain G, Fung WL, et al. Clinically detectable copy number variations in a Canadian catchment population of schizophrenia J Psychiatr Res. 2010;44(15):1005-1009.

66. Fung WL, McEvilly R, Fong J, Silversides CK, Chow EWC, Bassett AS. Elevated prevalence of generalized anxiety disorder in adults with 22q11.2 deletion syndrome. Am J Psychiatry. 2010;167(8):998.

67. Murphy KC, Jones LA, Owen MJ. High rates of schizophrenia in adults with velo-cardio-facial syndrome. Arch Gen Psychiatry. 1999;56(10):940-945.

68. van Amelsvoort T, Henry J, Morris R, et al. Cognitive deficits associated with schizophrenia in velo-cardio-facial syndrome. Schizophr Res. 2004;70(2-3):223-232.

69. Bassett AS, Chow EW, AbdelMalik P, Gheorghiu M, Husted J, Weksberg R. The schizophrenia phenotype in 22q11 deletion syndrome. Am J Psychiatry. 2003;160(9):1580-1586.

70. Chow EW, Watson M, Young DA, Bassett AS. Neurocognitive profile in 22q11 deletion syndrome and schizophrenia. Schizophr Res. 2006;87(1-3):270-278.

71. Stoddard J, Niendam T, Hendren R, Carter C, Simon TJ. Attenuated positive symptoms of psychosis in adolescents with chromosome 22q11.2 deletion syndrome. Schizophr Res. 2010;118(1-3): $118-121$.

72. Torres-Juan L, Rosell J, Sanchez-de-la-Torre M, Fibla J, Heine-Suner D. Analysis of meiotic recombination in $22 \mathrm{q} 11.2$, a region that frequently undergoes deletions and duplications. BMC Med Genet. 2007;8:14.

73. Bassett AS, Chow EW. 22q11 deletion syndrome: a genetic subtype of schizophrenia. Biol Psychiatry. 1999;46(7):882-891.

74. Antshel KM, Fremont W, Roizen NJ, et al. ADHD, major depressive disorder, and simple phobias are prevalent psychiatric conditions in youth with velocardiofacial syndrome. J Am Acad Child Adolesc Psychiatry. 2006;45(5):596-603.

75. Bassett AS, Chow EW, Husted J, et al. Premature death in adults with 22q11.2 deletion syndrome. J Med Genet. 2009;46(5):324-330.

76. Booij J, van Amelsvoort T, Boot E. Co-occurrence of early-onset Parkinson disease and 22q11.2 deletion syndrome: Potential role for dopamine transporter imaging. Am J Med Genet A. 2010;152A(11): 2937-2938.

77. De Smedt B, Swillen A, Verschaffel L, Ghesquiere P. Mathematical learning disabilities in children with 22q11.2 deletion syndrome: a review. Dev Disabil Res Rev. 2009;15(1):4-10. 
78. Green T, Gothelf D, Glaser B, et al. Psychiatric disorders and intellectual functioning throughout development in velocardiofacial (22q11.2 deletion) syndrome. J Am Acad Child Adolesc Psychiatry. 2009;48(11):1060-1068.

79. Hercher L, Bruenner G. Living with a child at risk for psychotic illness: the experience of parents coping with 22q11 deletion syndrome: an exploratory study. Am J Med Genet A. 2008;146A(18):2355-2360.

80. Jolin EM, Weller RA, Jessani NR, Zackai EH, McDonald-McGinn DM, Weller EB. Affective disorders and other psychiatric diagnoses in children and adolescents with 22q11.2 Deletion Syndrome. J Affect Disord. 2009;119(1-3):177-180.

81. Kapadia RK, Bassett AS. Recognizing a common genetic syndrome: 22q11.2 deletion syndrome. CMAJ. 2008;178(4):391-393.

82. Lawrence S, McDonald-McGinn DM, Zackai E, Sullivan KE. Thrombocytopenia in patients with chromosome 22q11.2 deletion syndrome. J Pediatr. 2003;143(2):277-278.

83. McDonald-McGinn DM, Kirschner R, Goldmuntz E, et al. The Philadelphia story: the 22q11.2 deletion: report on 250 patients. Genet Couns. 1999;10(1):11-24.

84. McDonald-McGinn DM, Zackai EH. Genetic counseling for the 22q11.2 deletion. Dev Disabil Res Rev. 2008;14(1):69-74.

85. Oskarsdottir S, Persson C, Eriksson BO, Fasth A. Presenting phenotype in 100 children with the 22q11 deletion syndrome. Eur J Pediatr. 2005;164(3):146-153.

86. Ryan AK, Goodship JA, Wilson DI, et al. Spectrum of clinical features associated with interstitial chromosome 22q11 deletions: a European collaborative study. J Med Genet. 1997;34(10):798-804.

87. Vantrappen G, Devriendt K, Swillen A, et al. Presenting symptoms and clinical features in 130 patients with the velo-cardio-facial syndrome. The Leuven experience. Genet Couns. 1999;10(1):3-9.

88. Zaleski C, Bassett AS, Tam K, Shugar AL, Chow EW, McPherson E. The co-occurrence of early onset Parkinson disease and 22q11.2 deletion syndrome. Am J Med Genet A. 2009;149A(3):525-528.

89. Chow EW, Husted J, Weksberg R, Bassett AS. Postmaturity in a genetic subtype of schizophrenia. Acta Psychiatr Scand. 2003;108(4): $260-268$.

90. Gothelf D, Eliez S, Thompson T, et al. COMT genotype predicts longitudinal cognitive decline and psychosis in 22q11.2 deletion syndrome. Nat Neurosci. 2005;8(11):1500-1502.

91. Vorstman JA, Chow EW, Ophoff RA, et al. Association of the PIK4CA schizophrenia-susceptibility gene in adults with the 22q11.2 deletion syndrome. Am J Med Genet B Neuropsychiatr Genet. 2009; $150 \mathrm{~B}(3): 430-433$

92. Guo T, McDonald-McGinn D, Blonska A, et al. Genotype and cardiovascular phenotype correlations with TBX1 in 1,022 velo-cardiofacial/digeorge/22q11.2 deletion syndrome patients. Hum Mutat. 2011;32(11):1278-1289.

93. Swaby JA, Silversides CK, Bekeschus SC, et al. Complex congenital heart disease in unaffected relatives of adults with 22q11.2 deletion syndrome. Am J Cardiol. 2011;107(3):466-471.

94. Bassett AS, Caluseriu O, Weksberg R, Young DA, Chow EW. CatecholO-methyl transferase and expression of schizophrenia in 73 adults with 22q11 deletion syndrome. Biol Psychiatry. 2007;61(10):1135-1140.

95. Boot E, Booij J, Abeling N, et al. Dopamine metabolism in adults with 22q11 deletion syndrome, with and without schizophrenia - relationship with COMT Val(1)/(1)Met polymorphism, gender and symptomatology. J Psychopharmacol. 2011;25(7):888-895.

96. Ikeda M, Williams N, Williams HJ, et al. Failure to confirm association between PIK4CA and psychosis in 22q11.2 deletion syndrome. Am J Med Genet B Neuropsychiatr Genet. 2010;153B(4):980-982.

97. Antshel KM, Shprintzen R, Fremont W, Higgins AM, Faraone SV, Kates WR. Cognitive and psychiatric predictors to psychosis in velocardiofacial syndrome: a 3-year follow-up study. J Am Acad Child Adolesc Psychiatry. 2010;49(4):333-344.

98. Gothelf D, Feinstein C, Thompson T, et al. Risk factors for the emergence of psychotic disorders in adolescents with 22q11.2 deletion syndrome. Am J Psychiatry. 2007;164(4):663-669.
99. Gothelf D, Hoeft F, Ueno T, et al. Developmental changes in multivariate neuroanatomical patterns that predict risk for psychosis in 22q11.2 deletion syndrome. J Psychiatr Res. 2011:45(3):322-331.

100. Chow EW, Ho A, Wei C, Voormolen EH, Crawley AP, Bassett AS. Association of schizophrenia in 22q11.2 deletion syndrome and gray matter volumetric deficits in the superior temporal gyrus. $\mathrm{Am} J$ Psychiatry. 2011;168(5):522-529.

101. Emsley R, Chiliza B, Schoeman R. Predictors of long-term outcome in schizophrenia. Curr Opin Psychiatry. 2008;21(2):173-177.

102. Bromet EJ, Kotov R, Fochtmann LJ, et al. Diagnostic shifts during the decade following first admission for psychosis. Am J Psychiatry. 2011;168(11):1186-1194.

103. Werner S, Stawski M. Knowledge, attitudes and training of professionals on dual diagnosis of intellectual disability and psychiatric disorder. J Intellect Disabil Res. 2011.

104. Badner JA, Gershon ES. Meta-analysis of whole-genome linkage scans of bipolar disorder and schizophrenia. Mol Psychiatry. 2002;7(4):405-411.

105. Lewis CM, Levinson DF, Wise LH, et al. Genome scan meta-analysis of schizophrenia and bipolar disorder, part II: Schizophrenia. Am J Hum Genet. 2003;73(1):34-48.

106. Ng MY, Levinson DF, Faraone SV, et al. Meta-analysis of 32 genome-wide linkage studies of schizophrenia. Mol Psychiatry. 2009;14(8):774-785.

107. Owen MJ, Williams NM, O'Donovan MC. The molecular genetics of schizophrenia: new findings promise new insights. Mol Psychiatry. 2004;9(1):14-27.

108. Waterwort DM, Bassett AS, Brzustowicz LM. Recent advances in the genetics of schizophrenia. Cell Mol Life Sci. 2002;59(2):331-348.

109. Blouin JL, Dombroski BA, Nath SK, et al. Schizophrenia susceptibility loci on chromosomes $13 \mathrm{q} 32$ and $8 \mathrm{p} 21$. Nat Genet. 1998;20(1):70-73.

110. Brzustowicz LM, Honer WG, Chow EW, et al. Linkage of familial schizophrenia to chromosome 13q32. Am J Hum Genet. 1999;65(4):1096-1103.

111. Brzustowicz LM, Hodgkinson KA, Chow EW, Honer WG, Bassett AS. Location of a major susceptibility locus for familial schizophrenia on chromosome 1q21-q22. Science. 2000;288(5466):678-682.

112. Ekelund J, Hovatta I, Parker A, et al. Chromosome 1 loci in Finnish schizophrenia families. Hum Mol Genet. 2001;10(15):1611-1617.

113. Gurling HM, Kalsi G, Brynjolfson J, et al. Genomewide genetic linkage analysis confirms the presence of susceptibility loci for schizophrenia, on chromosomes 1q32.2, 5q33.2, and 8p21-22 and provides support for linkage to schizophrenia, on chromosomes 11q23.3-24 and 20q12.111.23. Am J Hum Genet. 2001;68(3):661-673.

114. Holmans PA, Riley B, Pulver AE, et al. Genomewide linkage scan of schizophrenia in a large multicenter pedigree sample using single nucleotide polymorphisms. Mol Psychiatry. 2009;14(8):786-795.

115. Lin MW, Sham P, Hwu HG, Collier D, Murray R, Powell JF. Suggestive evidence for linkage of schizophrenia to markers on chromosome 13 in Caucasian but not Oriental populations. Hum Genet. 1997;99(3):417-420.

116. Shaw SH, Kelly M, Smith AB, et al. A genome-wide search for schizophrenia susceptibility genes. Am J Med Genet. 1998;81(5):364-376.

117. Stefansson H, Sigurdsson E, Steinthorsdottir V, et al. Neuregulin 1 and susceptibility to schizophrenia. Am J Hum Genet. 2002;71(4): 877-892.

118. Straub RE, MacLean CJ, O'Neill FA, Walsh D, Kendler KS. Support for a possible schizophrenia vulnerability locus in region 5q22-31 in Irish families. Mol Psychiatry. 1997;2(2):148-155.

119. Vieland VJ. Thermometers: something for statistical geneticists to think about. Hum Hered. 2006;61(3):144-156.

120. Faraone SV, Hwu HG, Liu CM, et al. Genome scan of Han Chinese schizophrenia families from Taiwan: confirmation of linkage to 10q22.3. Am J Psychiatry. 2006;163(10):1760-1766.

121. Goes FS, Zandi PP, Miao K, et al. Mood-incongruent psychotic features in bipolar disorder: familial aggregation and suggestive linkage to 2p11-q14 and 13q21-33. Am J Psychiatry. 2007;164(2):236-247. 
122. Suarez BK, Duan J, Sanders AR, et al. Genomewide linkage scan of 409 European-ancestry and African American families with schizophrenia: suggestive evidence of linkage at 8p23.3-p21.2 and 11p13.1-q14.1 in the combined sample. Am J Hum Genet. 2006;78(2):315-333.

123. Wratten NS, Memoli H, Huang Y, et al. Identification of a schizophrenia-associated functional noncoding variant in NOS1AP. Am J Psychiatry. 2009;166(4):434-441.

124. Gershon ES, Alliey-Rodriguez N, Liu C. After GWAS: searching for genetic risk for schizophrenia and bipolar disorder. Am J Psychiatry 2011;168(3):253-256.

125. Athanasiu L, Mattingsdal M, Kahler AK, et al. Gene variants associated with schizophrenia in a Norwegian genome-wide study are replicated in a large European cohort. J Psychiatr Res. 2010;44(12): 748-753.

126. Lencz T, Morgan TV, Athanasiou M, et al. Converging evidence for a pseudoautosomal cytokine receptor gene locus in schizophrenia. Mol Psychiatry. 2007;12(6):572-580.

127. Need AC, Ge D, Weale ME, et al. A genome-wide investigation of SNPs and CNVs in schizophrenia. PLoS Genet. 2009;5(2):e1000373.

128. Schanze D, Ekici AB, Gawlik M, Pfuhlmann B, Reis A, Stober G. Evaluation of risk loci for schizophrenia derived from genome-wide association studies in a German population. Am J Med Genet B Neuropsychiatr Genet. 2011;156(2):198-203.

129. Sullivan PF, Lin D, Tzeng JY, et al. Genomewide association for schizophrenia in the CATIE study: results of stage 1. Mol Psychiatry. 2008;13(6):570-584.

130. O'Donovan MC, Craddock N, Norton N, et al. Identification of loci associated with schizophrenia by genome-wide association and followup. Nat Genet. 2008;40(9):1053-1055.

131. Purcell SM, Wray NR, Stone JL, et al. Common polygenic variation contributes to risk of schizophrenia and bipolar disorder. Nature. 2009;460(7256):748-752.

132. Rietschel M, Mattheisen M, Degenhardt F, et al. Association between genetic variation in a region on chromosome 11 and schizophrenia in large samples from Europe. Mol Psychiatry. 2011.

133. Ripke S, Sanders AR, Kendler KS, et al. Genome-wide association study identifies five new schizophrenia loci. Nat Genet. 2011;43(10):969-976.

134. Shi J, Levinson DF, Duan J, et al. Common variants on chromosome 6p22.1 are associated with schizophrenia. Nature. 2009;460(7256): 753-757.

135. Stefansson H, Ophoff RA, Steinberg S, et al. Common variants conferring risk of schizophrenia. Nature. 2009;460(7256):744-747.

136. Yamada K, Iwayama Y, Hattori E, et al. Genome-wide association study of schizophrenia in Japanese population. PLoS One. 2011;6(6):e20468.

137. Yue WH, Wang HF, Sun LD, et al. Genome-wide association study identifies a susceptibility locus for schizophrenia in Han Chinese at 11p11.2. Nat Genet. 2011;43(12):1228-1231.

138. Crowe RR, Thompson JS, Flink R, Weinberger B. HLA antigens and schizophrenia. Arch Gen Psychiatry. 1979;36(2):231-233.

139. Eberhard G, Franzen G, Low B. Schizophrenia susceptibility and HL-A antigen. Neuropsychobiology. 1975;1(4):211-217.

140. Shi Y, Li Z, Xu Q, et al. Common variants on 8p12 and 1q24.2 confer risk of schizophrenia. Nat Genet. 2011;43(12):1224-1227.

141. Steinberg S, de Jong S, Andreassen OA, et al. Common variants at VRK2 and TCF4 conferring risk of schizophrenia. Hum Mol Genet. 2011;20(20):4076-4081.

142. Wang KS, Liu XF, Aragam N. A genome-wide meta-analysis identifies novel loci associated with schizophrenia and bipolar disorder. Schizophr Res. 2010;124(1-3):192-199.

143. Williams HJ, Norton N, Dwyer S, et al. Fine mapping of ZNF804A and genome-wide significant evidence for its involvement in schizophrenia and bipolar disorder. Mol Psychiatry. 2011;16(4):429-441.

144. Glessner JT, Reilly MP, Kim CE, et al. Strong synaptic transmission impact by copy number variations in schizophrenia. Proc Natl Acad Sci US A. 2010;107(23):10584-10589.
145. Arranz MJ, Rivera M, Munro JC. Pharmacogenetics of response to antipsychotics in patients with schizophrenia. CNS Drugs. 2011; 25(11):933-969.

146. Cacabelos R, Hashimoto R, Takeda M. Pharmacogenomics of antipsychotics efficacy for schizophrenia. Psychiatry Clin Neurosci. 2011; 65(1):3-19.

147. Hodgkinson KA, Murphy J, O’Neill S, Brzustowicz L, Bassett AS. Genetic counselling for schizophrenia in the era of molecular genetics. Can J Psychiatry. 2001;46(2):123-130.

148. Allen NC, Bagade S, McQueen MB, et al. Systematic meta-analyses and field synopsis of genetic association studies in schizophrenia: the SzGene database. Nat Genet. 2008;40(7):827-834.

149. Girard SL, Gauthier J, Noreau A, et al. Increased exonic de novo mutation rate in individuals with schizophrenia. Nat Genet. 2011;43(9): 860-863.

150. Xu B, Roos JL, Dexheimer P, et al. Exome sequencing supports a de novo mutational paradigm for schizophrenia. Nat Genet. 2011;43(9): 864-868.

151. Cook EH Jr, Scherer SW. Copy-number variations associated with neuropsychiatric conditions. Nature. 2008;455(7215):919-923.

152. Iafrate AJ, Feuk L, Rivera MN, et al. Detection of large-scale variation in the human genome. Nat Genet. 2004;36(9):949-951.

153. Lee $\mathrm{C}$, Scherer SW. The clinical context of copy number variation in the human genome. Expert Rev Mol Med. 2010;12:e8.

154. Redon R, Ishikawa S, Fitch KR, et al. Global variation in copy number in the human genome. Nature. 2006;444(7118):444-454.

155. Sebat J, Lakshmi B, Troge J, et al. Large-scale copy number polymorphism in the human genome. Science. 2004;305(5683):525-528.

156. Bassett AS. Chromosomal aberrations and schizophrenia. Autosomes. Br J Psychiatry. 1992;161:323-334.

157. Ingason A, Kirov G, Giegling I, et al. Maternally derived microduplications at 15q11-q13: implication of imprinted genes in psychotic illness. Am J Psychiatry. 2011;168(4):408-417.

158. Grozeva D, Kirov G, Ivanov D, et al. Rare copy number variants: a point of rarity in genetic risk for bipolar disorder and schizophrenia. Arch Gen Psychiatry. 2010;67(4):318-327.

159. International Schizophrenia Consortium. Rare chromosomal deletions and duplications increase risk of schizophrenia. Nature. 2008;455(7210):237-241.

160. Kirov G, Grozeva D, Norton N, et al. Support for the involvement of large copy number variants in the pathogenesis of schizophrenia. Hum Mol Genet. 2009;18(8):1497-1503.

161. Kirov G, Pocklington AJ, Holmans P, et al. De novo CNV analysis implicates specific abnormalities of postsynaptic signalling complexes in the pathogenesis of schizophrenia. Mol Psychiatry. 2012;17(2):142-153.

162. Magri C, Sacchetti E, Traversa M, et al. New copy number variations in schizophrenia. PLoS One. 2010;5(10):e13422.

163. Melhem N, Middleton F, McFadden K, et al. Copy number variants for schizophrenia and related psychotic disorders in oceanic palau: risk and transmission in extended pedigrees. Biol Psychiatry. 2011;70(12):1115-1121.

164. Stefansson H, Rujescu D, Cichon S, et al. Large recurrent microdeletions associated with schizophrenia. Nature. 2008;455(7210):232-236.

165. Moreno-De-Luca D, Mulle JG, Kaminsky EB, et al. Deletion 17q12 is a recurrent copy number variant that confers high risk of autism and schizophrenia. Am J Hum Genet. 2010;87(5):618-630.

166. Levinson DF, Duan J, Oh S, et al. Copy number variants in schizophrenia: confirmation of five previous findings and new evidence for 3q29 microdeletions and VIPR2 duplications. Am J Psychiatry. 2011;168(3):302-316.

167. Ingason A, Rujescu D, Cichon S, et al. Copy number variations of chromosome 16p13.1 region associated with schizophrenia. Mol Psychiatry. 2011;16(1):17-25.

168. Brunetti-Pierri N, Berg JS, Scaglia F, et al. Recurrent reciprocal 1q21.1 deletions and duplications associated with microcephaly or macrocephaly and developmental and behavioral abnormalities. Nat Genet. 2008;40(12):1466-1471. 
169. Doornbos M, Sikkema-Raddatz B, Ruijvenkamp CA, et al. Nine patients with a microdeletion 15q11.2 between breakpoints 1 and 2 of the Prader-Willi critical region, possibly associated with behavioural disturbances. Eur J Med Genet. 2009;52(2-3):108-115.

170. Greenway SC, Pereira AC, Lin JC, et al. De novo copy number variants identify new genes and loci in isolated sporadic tetralogy of Fallot. Nat Genet. 2009;41(8):931-935.

171. Hannes FD, Sharp AJ, Mefford HC, et al. Recurrent reciprocal deletions and duplications of 16p13.11: the deletion is a risk factor for MR/MCA while the duplication may be a rare benign variant. $J$ Med Genet. 2009;46(4):223-232.

172. Harvard C, Strong E, Mercier E, et al. Understanding the impact of 1q21.1 copy number variant. Orphanet J Rare Dis. 2011;6:54.

173. de Kovel CG, Trucks H, Helbig I, et al. Recurrent microdeletions at $15 q 11.2$ and 16p13.11 predispose to idiopathic generalized epilepsies. Brain. 2010;133(Pt 1):23-32.

174. Mefford HC, Clauin S, Sharp AJ, et al. Recurrent reciprocal genomic rearrangements of $17 \mathrm{q} 12$ are associated with renal disease, diabetes, and epilepsy. Am J Hum Genet. 2007;81(5):1057-1069.

175. Mefford HC, Sharp AJ, Baker C, et al. Recurrent rearrangements of chromosome 1q21.1 and variable pediatric phenotypes. NEngl J Med. 2008;359(16):1685-1699.

176. Mefford HC, Cooper GM, Zerr T, et al. A method for rapid, targeted CNV genotyping identifies rare variants associated with neurocognitive disease. Genome Res. 2009;19(9):1579-1585.

177. Nagamani SC, Erez A, Shen J, et al. Clinical spectrum associated with recurrent genomic rearrangements in chromosome 17q12. Eur J Hum Genet. 2010;18(3):278-284.

178. Ullmann R, Turner G, Kirchhoff M, et al. Array CGH identifies reciprocal 16p13.1 duplications and deletions that predispose to autism and/ or mental retardation. Hum Mutat. 2007;28(7):674-682.

179. Williams NM, Zaharieva I, Martin A, et al. Rare chromosomal deletions and duplications in attention-deficit hyperactivity disorder: a genome-wide analysis. Lancet. 2010;376(9750):1401-1408.

180. Bassett AS. Parental origin, DNA structure, and the schizophrenia spectrum. Am J Psychiatry. 2011;168(4):350-353.

181. Horowitz A, Shifman S, Rivlin N, Pisante A, Darvasi A. A survey of the 22q11 microdeletion in a large cohort of schizophrenia patients. Schizophr Res. 2005;73(2-3):263-267.

182. Walsh T, McClellan JM, McCarthy SE, et al. Rare structural variants disrupt multiple genes in neurodevelopmental pathways in schizophrenia. Science. 2008;320(5875):539-543.

183. Sporn A, Addington A, Reiss AL, et al. 22q11 deletion syndrome in childhood onset schizophrenia: an update. Mol Psychiatry. 2004;9(3):225-226.

184. Rapoport JL, Addington AM, Frangou S, Psych MR. The neurodevelopmental model of schizophrenia: update 2005. Mol Psychiatry. 2005;10(5):434-449.

185. Girirajan S, Eichler EE. Phenotypic variability and genetic susceptibility to genomic disorders. Hum Mol Genet. 2010;19(R2):R176-R187.

186. Costain G, Chow EW, Ray PN, Bassett AS. Caregiver and adult patient perspectives on the importance of a diagnosis of $22 \mathrm{q} 11.2$ deletion syndrome. J Intellect Disabil Res. 2011.

187. Hodgkinson K, Pullman D. Duty to warn and genetic disease. Can J Cardiovasc Nurs. 2010;20(1):12-15.

188. Piggins HD. Schizophrenia: zooming in on a gene. Nature. 2011; 471(7339):455-456.

189. Green ED, Guyer MS. Charting a course for genomic medicine from base pairs to bedside. Nature. 2011;470(7333):204-213.

190. Scherer SW, Dawson G. Risk factors for autism: translating genomic discoveries into diagnostics. Hum Genet. 2011;130(1):123-148.

191. Family history and BRCA $1 / 2$ testing for identifying women at risk for inherited breast/ovarian cancer: AACE review. http://www.cdc. gov/genomics/gtesting/ACCE/fbr.htm

192. Miller FA, Hayeems RZ, Bytautas JP. What is a meaningful result? Disclosing the results of genomic research in autism to research participants. Eur J Hum Genet. 2010;18(8):867-871.
193. Bassett AS, Bury A, Hodgkinson KA, Honer WG. Reproductive fitness in familial schizophrenia. Schizophr Res. 1996;21(3): 151-160.

194. Bundy H, Stahl D, MacCabe JH. A systematic review and meta-analysis of the fertility of patients with schizophrenia and their unaffected relatives. Acta Psychiatr Scand. 2011;123(2):98-106.

195. Mitchell PB, Meiser B, Wilde A, et al. Predictive and diagnostic genetic testing in psychiatry. Clin Lab Med. 2010;30(4): 829-846.

196. Tsuang DW, Faraone SV, Tsuang MT. Genetic counseling for psychiatric disorders. Curr Psychiatry Rep. 2001;3(2):138-143.

197. Feret H, Conway L, Austin JC. Genetic counselors' attitudes towards individuals with schizophrenia: desire for social distance and endorsement of stereotypes. Patient Educ Couns. 2011;82(1): 69-73.

198. Monaco LC, Conway L, Valverde K, Austin JC. Exploring genetic counselors' perceptions of and attitudes towards schizophrenia. Public Health Genomics. 2010;13(1):21-26.

199. Finucane B. Genetic counseling for women with intellectual disabilities. In: LeRoy BS, Veach PM, Bartels DM, editors. Genetic Counseling Practice: Advanced Concepts and Skills. Hoboken: WileyBlackwell; 2010:470-507.

200. Taylor MR, Edwards JG, Ku L. Lost in transition: challenges in the expanding field of adult genetics. Am JMed Genet C Semin Med Genet. 2006;142C(4):294-303.

201. Farwig K, Harmon AG, Fontana KM, Mervis CB, Morris CA. Genetic counseling of adults with Williams syndrome: a first study. Am J Med Genet C Semin Med Genet. 2010;154C(2):307-315.

202. Lee C, Iafrate AJ, Brothman AR. Copy number variations and clinical cytogenetic diagnosis of constitutional disorders. Nat Genet. 2007; 39(7 Suppl):S48-S54.

203. Austin JC, Peay HL. Applications and limitations of empiric data in provision of recurrence risks for schizophrenia: a practical review for healthcare professionals providing clinical psychiatric genetics consultations. Clin Genet. 2006;70(3):177-187.

204. Peay HL, Austin JC. How to Talk with Families About Genetics and Psychiatric Illness. New York: WW Norton and Company; 2011.

205. Simpson SA, Besson J, Alexander D, Allan K, Johnston AW. One hundred requests for predictive testing for Huntington's disease. Clin Genet. 1992;41(6):326-330.

206. Tyler A, Morris M, Lazarou L, Meredith L, Myring J, Harper P. Presymptomatic testing for Huntington's disease in Wales 1987-1990. Br J Psychiatry. 1992;161:481-488.

207. Xu B, Woodroffe A, Rodriguez-Murillo L, et al. Elucidating the genetic architecture of familial schizophrenia using rare copy number variant and linkage scans. Proc Natl Acad Sci U S A. 2009;106(39): 16746-16751.

208. Al-Chalabi A, Lewis CM. Modelling the effects of penetrance and family size on rates of sporadic and familial disease. Hum Hered. 2011;71(4):281-288.

209. Yang J, Visscher PM, Wray NR. Sporadic cases are the norm for complex disease. Eur J Hum Genet. 2010;18(9):1039-1043.

210. Shulman JM, De Jager PL, Feany MB. Parkinson's disease: genetics and pathogenesis. Annu Rev Pathol. 2011;6:193-222.

211. Guttmacher AE, Collins FS, Carmona RH. The family history - more important than ever. N Engl J Med. 2004;351(22):2333-2336.

212. Papadimitriou GN, Dikeos DG. How does recent knowledge on the heredity of schizophrenia affect genetic counseling? Curr Psychiatry Rep. 2003;5(4):239-240.

213. Reveley A. Genetic counselling for schizophrenia. Br J Psychiatry. 1985;147:107-112.

214. Tsuang MT. Genetic counseling for psychiatric patients and their families. Am J Psychiatry. 1978;135(12):1465-1475.

215. Hunter MJ, Hippman C, Honer WG, Austin JC. Genetic counseling for schizophrenia: a review of referrals to a provincial medical genetics program from 1968 to 2007. Am J Med Genet A. 2010;152A(1): 147-152. 
216. Lyus VL. The importance of genetic counseling for individuals with schizophrenia and their relatives: potential clients' opinions and experiences. Am J Med Genet B Neuropsychiatr Genet. 2007;144B(8):1014-1021.

217. Austin JC, Honer WG. Psychiatric genetic counselling for parents of individuals affected with psychotic disorders: a pilot study. Early Interv Psychiatry. 2008;2(2):80-89.

218. Torrey EF. Surviving Schizophrenia: A Manual for Families, Patients, and Providers. 5th ed. New York, NY: Collins; 2006

219. Bruder CE, Piotrowski A, Gijsbers AA, et al. Phenotypically concordant and discordant monozygotic twins display different DNA copynumber-variation profiles. Am J Hum Genet. 2008;82(3):763-771.

220. Dempster EL, Pidsley R, Schalkwyk LC, et al. Disease-associated epigenetic changes in monozygotic twins discordant for schizophrenia and bipolar disorder. Hum Mol Genet. 2011;20(24):4786-4796.

221. Kato T, Iwamoto K, Kakiuchi C, Kuratomi G, Okazaki Y. Genetic or epigenetic difference causing discordance between monozygotic twins as a clue to molecular basis of mental disorders. Mol Psychiatry. 2005;10(7):622-630.

222. Maiti S, Kumar KH, Castellani CA, O'Reilly R, Singh SM. Ontogenetic de novo copy number variations (CNVs) as a source of genetic individuality: studies on two families with MZD twins for schizophrenia. PLoS One. 2011;6(3):e17125.

223. Husted JA, Ahmed R, Chow EW, Brzustowicz LM, BassettAS. Childhood trauma and genetic factors in familial schizophrenia associated with the NOS1AP gene. Schizophr Res. 2010;121(1-3):187-192.

224. van Os J, Kenis G, Rutten BP. The environment and schizophrenia. Nature. 2010;468(7321):203-212.

225. Kurnit DM, Layton WM, Matthysse S. Genetics, chance, and morphogenesis. Am J Hum Genet. 1987;41(6):979-995.

226. Ruvinsky A. Genetics and Randomness. Boca Raton, FL: CRC Press; 2010.

227. Lichtenstein P, Bjork C, Hultman CM, Scolnick E, Sklar P, Sullivan PF Recurrence risks for schizophrenia in a Swedish national cohort Psychol Med. 2006;36(10):1417-1425.

228. Slatkin M. Genotype-specific recurrence risks as indicators of the genetic architecture of complex diseases. Am J Hum Genet. 2008;83(1):120-126.

229. Wray NR, Goddard ME, Visscher PM. Prediction of individual genetic risk to disease from genome-wide association studies. Genome Res. 2007;17(10):1520-1528.

230. Slatkin M. Epigenetic inheritance and the missing heritability problem. Genetics. 2009;182(3):845-850.

231. Lander ES. Initial impact of the sequencing of the human genome Nature. 2011;470(7333):187-197.

232. Drmanac R. The advent of personal genome sequencing. Genet Med 2011;13(3):188-190.

233. Greenspan SI, Brazelton TB, Cordero J, et al. Guidelines for early identification, screening, and clinical management of children with autism spectrum disorders. Pediatrics. 2008;121(4):828-830.

234. Miles JH. Autism spectrum disorders - a genetics review. Genet Med. 2011;13(4):278-294.

235. Kjeldsen MJ, Kyvik KO, Christensen K, Friis ML. Genetic and environmental factors in epilepsy: a population-based study of 11900 Danish twin pairs. Epilepsy Res. 2001;44(2-3):167-178.

236. Mulley JC, Dibbens LM. Genetic variations and associated pathophysiology in the management of epilepsy. The Application of Clinical Genetics. 2011;4:113-125.

237. Pal DK, Pong AW, Chung WK. Genetic evaluation and counseling for epilepsy. Nat Rev Neurol. 2010;6(8):445-453.

238. Poduri A, Lowenstein D. Epilepsy genetics - past, present, and future. Curr Opin Genet Dev. 2011;21(3):325-332.

239. Sharma K. Genetic epidemiology of epilepsy: a twin study. Neurol India. 2005;53(1):93-98.

240. Do CB, Tung JY, Dorfman E, et al. Web-based genome-wide association study identifies two novel loci and a substantial genetic component for Parkinson's disease. PLoS Genet. 2011;7(6):e1002141.
241. Elbaz A, Bower JH, Maraganore DM, et al. Risk tables for parkinsonism and Parkinson's disease. J Clin Epidemiol. 2002;55(1):25-31.

242. Schulte C, Gasser T. Genetic basis of Parkinson's disease: inheritance, penetrance, and expression. The Application of Clinical Genetics. 2011;4(67-80):67.

243. Toft M, Ross OA. Copy number variation in Parkinson's disease. Genome Med. 2010;2(9):62.

244. Ballard C, Gauthier S, Corbett A, Brayne C, Aarsland D, Jones E. Alzheimer's disease. Lancet. 2011;377(9770):1019-1031.

245. Bertram L, Lill CM, Tanzi RE. The genetics of Alzheimer disease: back to the future. Neuron. 2010;68(2):270-281.

246. Gatz M, Reynolds CA, Fratiglioni L, et al. Role of genes and environments for explaining Alzheimer disease. Arch Gen Psychiatry. 2006;63(2):168-174.

247. Goldman JS, Hahn SE, Catania JW, et al. Genetic counseling and testing for Alzheimer disease: joint practice guidelines of the American College of Medical Genetics and the National Society of Genetic Counselors. Genet Med. 2011;13(6):597-605.

248. Coulter ME, Miller DT, Harris DJ, et al. Chromosomal microarray testing influences medical management. Genet Med. 2011;13(9): 770-776.

249. Basel-Vanagaite L, Goldberg-Stern H, Mimouni-Bloch A, Shkalim V, Bohm D, Kohlhase J. An emerging 1q21.1 deletion-associated neurodevelopmental phenotype. J Child Neurol. 2011;26(1):113-116.

250. Brunet A, Armengol L, Heine D, et al. BAC array CGH in patients with Velocardiofacial syndrome-like features reveals genomic aberrations on chromosome region 1q21.1. BMC Med Genet. 2009;10:144.

251. Christiansen J, Dyck JD, Elyas BG, et al. Chromosome 1q21.1 contiguous gene deletion is associated with congenital heart disease. Circ Res. 2004;94(11):1429-1435.

252. Ikeda M, Aleksic B, Kirov G, et al. Copy number variation in schizophrenia in the Japanese population. Biol Psychiatry. 2010;67(3): 283-286.

253. Sahoo T, Theisen A, Rosenfeld JA, et al. Copy number variants of schizophrenia susceptibility loci are associated with a spectrum of speech and developmental delays and behavior problems. Genet Med. 2011;13(10):868-880.

254. Vu TH, Coccaro EF, Eichler EE, Girirajan S. Genomic architecture of aggression: rare copy number variants in intermittent explosive disorder. Am J Med Genet B Neuropsychiatr Genet. 2011;156B(7): $808-816$.

255. Ballif BC, Theisen A, Coppinger J, et al. Expanding the clinical phenotype of the 3q29 microdeletion syndrome and characterization of the reciprocal microduplication. Mol Cytogenet. 2008;1:8.

256. Clayton-Smith J, Giblin C, Smith RA, Dunn C, Willatt L. Familial 3q29 microdeletion syndrome providing further evidence of involvement of the 3q29 region in bipolar disorder. Clin Dysmorphol. 2010;19(3): 128-132.

257. Digilio MC, Bernardini L, Mingarelli R, et al. 3q29 Microdeletion: a mental retardation disorder unassociated with a recognizable phenotype in two mother-daughter pairs. Am J Med Genet A. 2009;149A(8): 1777-1781.

258. Mulle JG, Dodd AF, McGrath JA, et al. Microdeletions of 3q29 confer high risk for schizophrenia. Am J Hum Genet. 2010;87(2):229-236.

259. Quintero-Rivera F, Sharifi-Hannauer P, Martinez-Agosto JA. Autistic and psychiatric findings associated with the 3q29 microdeletion syndrome: case report and review. Am J Med Genet A. 2010;152A(10):2459-2467.

260. Vacic V, McCarthy S, Malhotra D, et al. Duplications of the neuropeptide receptor gene VIPR2 confer significant risk for schizophrenia. Nature. 2011;471(7339):499-503.

261. Willatt L, Cox J, Barber J, et al. 3q29 microdeletion syndrome: clinical and molecular characterization of a new syndrome. Am J Hum Genet. 2005;77(1):154-160.

262. Browne CE, Dennis NR, Maher E, et al. Inherited interstitial duplications of proximal 15q: genotype-phenotype correlations. Am J Hum Genet. 1997;61(6):1342-1352. 
263. Chamberlain SJ, Lalande M. Neurodevelopmental disorders involving genomic imprinting at human chromosome 15q11-q13. Neurobiol Dis. 2010;39(1):13-20.

264. Cook EH Jr, Lindgren V, Leventhal BL, et al. Autism or atypical autism in maternally but not paternally derived proximal $15 q$ duplication. Am J Hum Genet. 1997;60(4):928-934.

265. Gurrieri F, Battaglia A, Torrisi L, et al. Pervasive developmental disorder and epilepsy due to maternally derived duplication of 15q11-q13. Neurology. 1999;52(8):1694-1697.

266. Hogart A, Wu D, LaSalle JM, Schanen NC. The comorbidity of autism with the genomic disorders of chromosome 15q11.2-q13. Neurobiol Dis. 2010;38(2):181-191.

267. Michelson M, Eden A, Vinkler C, et al. Familial partial trisomy 15q11-13 presenting as intractable epilepsy in the child and schizophrenia in the mother. Eur J Paediatr Neurol. 2011;15(3):230-233.

268. Thomas JA, Johnson J, Peterson Kraai TL, et al. Genetic and clinical characterization of patients with an interstitial duplication 15q11-q13, emphasizing behavioral phenotype and response to treatment. Am J Med Genet A. 2003;119A(2):111-120.

269. Ben-Shachar S, Lanpher B, German JR, et al. Microdeletion 15q13.3: a locus with incomplete penetrance for autism, mental retardation, and psychiatric disorders. J Med Genet. 2009;46(6):382-388.

270. van Bon BW, Mefford HC, Menten B, et al. Further delineation of the 15 q13 microdeletion and duplication syndromes: a clinical spectrum varying from non-pathogenic to a severe outcome. J Med Genet. 2009;46(8):511-523.

271. Cubells JF, Deoreo EH, Harvey PD, et al. Pharmaco-genetically guided treatment of recurrent rage outbursts in an adult male with $15 \mathrm{q} 13.3$ deletion syndrome. Am J Med Genet A. 2011;155A(4):805-810.

272. Dibbens LM, Mullen S, Helbig I, et al. Familial and sporadic $15 q 13.3$ microdeletions in idiopathic generalized epilepsy: precedent for disorders with complex inheritance. Hum Mol Genet. 2009;18(19): 3626-3631.

273. Helbig I, Mefford HC, Sharp AJ, et al. 15q13.3 microdeletions increase risk of idiopathic generalized epilepsy. Nat Genet. 2009;41(2): $160-162$.

274. Masurel-Paulet A, Andrieux J, Callier P, et al. Delineation of 15q13.3 microdeletions. Clin Genet. 2010;78(2):149-161.

275. Miller DT, Shen Y, Weiss LA, et al. Microdeletion/duplication at 15q13.2q13.3 among individuals with features of autism and other neuropsychiatric disorders. J Med Genet. 2009;46(4):242-248.

276. Pagnamenta AT, Wing K, Sadighi Akha E, et al. A 15q13.3 microdeletion segregating with autism. Eur J Hum Genet. 2009;17(5):687-692.

277. Sharp AJ, Mefford HC, Li K, et al. A recurrent 15q13.3 microdeletion syndrome associated with mental retardation and seizures. Nat Genet. 2008;40(3):322-328.
278. Shinawi M, Schaaf CP, Bhatt SS, et al. A small recurrent deletion within 15 q13.3 is associated with a range of neurodevelopmental phenotypes. Nat Genet. 2009;41(12):1269-1271.

279. Bedoyan JK, Kumar RA, Sudi J, et al. Duplication $16 \mathrm{p} 11.2$ in a child with infantile seizure disorder. Am J Med Genet A. 2010;152A(6): 1567-1574.

280. Fernandez BA, Roberts W, Chung B, et al. Phenotypic spectrum associated with de novo and inherited deletions and duplications at 16 p11.2 in individuals ascertained for diagnosis of autism spectrum disorder. J Med Genet. 2010;47(3):195-203.

281. Lionel AC, Crosbie J, Barbosa N, et al. Rare copy number variation discovery and cross-disorder comparisons identify risk genes for ADHD. Sci Transl Med. 2011;3(95):95ra75.

282. McCarthy SE, Makarov V, Kirov G, et al. Microduplications of 16p11.2 are associated with schizophrenia. Nat Genet. 2009;41(11): 1223-1227.

283. Marshall CR, Noor A, Vincent JB, et al. Structural variation of chromosomes in autism spectrum disorder. Am J Hum Genet. 2008;82(2): 477-488.

284. Rosenfeld JA, Coppinger J, Bejjani BA, et al. Speech delays and behavioral problems are the predominant features in individuals with developmental delays and 16p11.2 microdeletions and microduplications. J Neurodev Disord. 2010;2(1):26-38.

285. Schaaf CP, Goin-Kochel RP, Nowell KP, et al. Expanding the clinical spectrum of the $16 \mathrm{p} 11.2$ chromosomal rearrangements: three patients with syringomyelia. Eur J Hum Genet. 2011;19(2):152-156.

286. Shen Y, Dies KA, Holm IA, et al. Clinical genetic testing for patients with autism spectrum disorders. Pediatrics. 2010;125(4):e727-e735.

287. Shinawi M, Liu P, Kang SH, et al. Recurrent reciprocal 16p11.2 rearrangements associated with global developmental delay, behavioural problems, dysmorphism, epilepsy, and abnormal head size. J Med Genet. 2010;47(5):332-341.

288. Weiss LA, Shen Y, Korn JM, et al. Association between microdeletion and microduplication at 16p11.2 and autism. $N$ Engl J Med. 2008; 358(7):667-675

289. Goodship J, Cross I, LiLing J, Wren C. A population study of chromosome 22q11 deletions in infancy. Arch Dis Child. 1998;79(4): 348-351.

290. Rees E, Moskvina V, Owen MJ, O’Donovan MC, Kirov G. De novo rates and selection of schizophrenia-associated copy number variants. Biol Psychiatry. 2011;70(12):1109-1114.

291. Vassos E, Collier DA, Holden S, et al. Penetrance for copy number variants associated with schizophrenia. Hum Mol Genet. 2010;19(17): 3477-3481.
The Application of Clinical Genetics

\section{Publish your work in this journal}

The Application of Clinical Genetics is an international, peer-reviewed open access journal that welcomes laboratory and clinical findings in the field of human genetics. Specific topics include: Population genetics; Functional genetics; Natural history of genetic disease; Management of genetic disease; Mechanisms of genetic disease; Counselling and

\section{Dovepress}

ethical issues; Animal models; Pharmacogenetics; Prenatal diagnosis; Dysmorphology. The manuscript management system is completely online and includes a very quick and fair peer-review system, which is all easy to use. Visit http://www.dovepress.com/testimonials.php to read real quotes from published authors. 